\title{
Erosion hazard evaluation for soil conservation planning that sustains life expectancy of A horizon: the Black Soil Region of China
}

\author{
Tianyu Zhang ${ }^{1}$ \\ ${ }^{1}$ Northeast Normal University
}

May 8, 2020

\begin{abstract}
The black soil region of northeast China is one of the most productive regions of the world. The depth of A horizon is rapidly decreasing due to excessive erosion. A strategy for erosion hazard evaluation and soil conservation planning has been proposed and tested on the region. Climate, geomorphology, DEM, soil, landuse, runoff plot and corn yield data were compiled. Soil erosion rate, A horizon thickness and corn yield under six conservation scenarios during $2020 \sim 2200$ was predicted. The six scenarios include Present (continue present practices), Contour (contour tillage), Straw (straw incorporated in tillage layer), Combo 1 (contour tillage and terracing etc.), No-till (no-till farming) and Combo 2 (partially Combo 1 and partially No-till). Current soil life expectancy of A horizon (SLEA), which is the time until a critical horizon thickness needed for sustaining crop production is reached, was calculated for each scenario. Erosion hazard degrees were determined with SLEA. Croplands with SLEA of $<0$ a, 0 a 20 a, 20 a 100 a, 100 a 1000 a and [?]1000 a, were classified as "Damaged", "High hazard", "Moderate hazard", "Low hazard" and "No hazard", respectively. Current area ratio of "Damaged" and "High hazard" and "Moderate hazard" was found to be $8 \%, 5 \%$, and $22 \%$, respectively. The optimum conservation practice was found to be No-till for "Damaged", "Combo 2" for "High hazard", "Moderate hazard" and "Low hazard" and Present for "No hazard". An optimum conservation schedule was also suggested for each township to maintain all soils to have an A horizon above $20 \mathrm{~cm}$.
\end{abstract}

\section{INTRODUCTION}

1.1 Soil erosion, A horizon thickness and crop yield

Soil erosion is a serious problem due to inadequate and inappropriate management of land (Benaud et al., 2020). By 2011, 1.3 million $\mathrm{km}^{2}$ of China's lands were still suffering from water erosion (Ministry of Water Resources of China, 2013). The area for moderate erosion (1.9 to $3.7 \mathrm{~mm} / \mathrm{a}$ ), strong erosion (3.7 to 5.9 $\mathrm{mm} / \mathrm{a}$ ), very strong erosion (5.9 to $11.1 \mathrm{~mm} / \mathrm{a}$ ) and extremely strong erosion ([?]11.1 mm/a) was 351400 $\mathrm{km}^{2}, 168700 \mathrm{~km}^{2}, 76300 \mathrm{~km}^{2}$ and $29200 \mathrm{~km}^{2}$ by 2011 , respectively.

Given that the A horizon is located at soil surface, it is most affected by human activities. The A horizon is richer in organic matter and more fertile than the underneath horizons. In the Black Soil Region (BSR) of China, the soil organic matter content (SOM) of the A horizon is significantly higher than those of the underneath horizons (Figure 1). The mean SOM of the A horizon is 3.5\%, 2.5\% and $4.3 \%$ for black soil, chernozem and dark brown soil, respectively. On average, SOM of the A horizon is 2.4 times that of the underneath horizons. This ratio can be more than 10 for some newly reclaimed dark-brown soil (Figure 1C, profile 2).

The A horizon is the main source of nutrients for crops. For soils without a B horizon, such as is common in the BSR, the A horizon serves as the main source of water as the available water capacity (AWC) of mollic epipedon is extremely high while $\mathrm{C}$ horizon material is extremely low. The crop yield is, therefore, 
closely related to A horizon thickness $\left(\mathrm{Th}_{A}\right)$. Liu et al. (2013) found that for every $1 \mathrm{~cm}$ decrease in A horizon thickness in the BSR, there was a corresponding $2 \%$ decrease in crop yield. The crop yield declined $30 \%^{\sim} 40 \%$ when the A horizon eroded away completely in the humid eastern United States (NSESPRPC, 1981). Some studies indicated that crop yield will decline sharply as $\mathrm{Th}_{A}$ falls below a critical threshold (Wen and Easter, 1987; Sparovek and Schnug, 2001; Fenton et al., 2005; Zhang et al., 2006; Sui et al., 2009; Feng et al., 2018). Soil desurfacing experiments in the BSR showed the critical thickness to minimize crop yield loss is about $20 \mathrm{~cm}$ (Figure 2). WhenTh $\mathrm{T}_{A}$ is above $20 \mathrm{~cm}$, crop yield declines by $7 \%$ with every $10 \mathrm{~cm}$ loss of $\mathrm{Th}_{A}$, but $17 \%$ when $\mathrm{Th}_{A}$ is below $20 \mathrm{~cm}$. Mollisols in the USA similar to the soils in the BSR showed less dramatic trends as the BSR, with crop yields declining by $3 \%$ for every $10 \mathrm{~cm}$ loss for $\mathrm{Th}_{A}$ above 25 $\mathrm{cm}$. The ratio will become $5 \%$ as $\mathrm{Th}_{A}$ is below $25 \mathrm{~cm}$ (Fenton et al., 2005). The critical thickness of $20^{\sim} 25$ $\mathrm{cm}$ is mainly due more than half of crop roots being distributed in the top $20 \mathrm{~cm}$ of soils (Fan et al., 2016). Compacted layers will motivate roots to grow horizontally and cause almost all roots to distribute in the top $20 \mathrm{~cm}$ (Cannell et al., 1985, Ball-Coelho et al., 2010). This phenomenon is prevalent and significant in the BSR and other parts of China. For $82 \%$ of cornfields in China, $90 \%$ of the roots are distributed in the top $20 \mathrm{~cm}$ (Wang et al., 2018). As a result, in soils with original A horizon thicker than $20 \mathrm{~cm}$, most roots will distribute in the fertile and high AWC A horizon. Such crops will grow in a more favorable condition. In contrast, in soils with an A horizon thinner than $20 \mathrm{~cm}$, roots will have to distribute in the infertile and low AWC underneath horizon or be limited in nutrient and water availability. Thus, crops will grow in a stressed condition.

The situation is more complicated for ploughed croplands. Ploughing can mix materials from infertile horizons underneath with the A horizon (Figure 3), thereby diluting the A horizon benefits. The diluted A horizon will be lighter in color, less fertile and lower in AWC. Even with a thickness $20 \mathrm{~cm}$ the A horizon becomes less productive (Figure 1 and 3). The decline in crop yield is obvious and irreversible in large part to loss of AWC and potential increase leaching of the fertilizers applied (Figure 2). For those soils with underneath horizons mainly composed of sands or rocks, soil productivity loss will be even more dramatic as the A horizon is eroded away and become negligible when the A horizon is gone. This explains why Liu et al (2013) found a $20 \%$ loss in crop yield per $10 \mathrm{~cm}$ decrease in A horizon. Once the A horizon is gone or diluted by $\mathrm{C}$ material underneath mixing, the degradation is irreversible.

The erosion hazard should not be evaluated merely by erosion rate but also according to the thickness of the A horizon. Suppose region 1 has a higher erosion rate $(2 \mathrm{~mm} / \mathrm{a})$ than region $2(1 \mathrm{~mm} / \mathrm{a})$, but has a thicker A horizon $(100 \mathrm{~cm})$ than region $2(30 \mathrm{~cm})$. In less than 300 years, region 2 cannot be farmed due to soil erosion, while region 2 is still productive. A better index for evaluation is soil life expectancy (SLE) expressed in years (a). SLE is the time until a critical soil thickness for sustaining crop production is reached (Sparovek and Schnug, 2001; Paroissien et al., 2015). SLE of A horizon $\left(\mathrm{SLE}_{\mathrm{A}}\right)$ can be calculated with following equation.

$\mathrm{SLE}_{A}=\frac{10\left(\mathrm{Th}_{A}-\mathrm{Th}_{\mathrm{CR}}\right)}{E_{r}}(1)$

Where $\mathrm{Th}_{A}$ is A horizon thickness $(\mathrm{cm}), \mathrm{Th}_{\mathrm{CR}}$ is critical horizon thickness $(\mathrm{cm})$, and $E_{r}$ is the soil erosion rate $(\mathrm{mm} / \mathrm{a}) . T \mathrm{Th}_{\mathrm{CR}}$ is related to root distribution and may vary among crops and regions. $\mathrm{ATh}_{\mathrm{CR}}$ of 20 $\mathrm{cm}$ was used for Crotalaria junceain Brazil (Sparovek and Schnug, 2001). A SLE of 50 indicates that crop yield will decline sharply, after 50 years. SLE has already been applied to evaluate erosion hazard in Brazil and France (Sparovek and Schnug, 2001; Paroissien et al., 2015). Reducing crop yield is the ultimate soil erosion hazard for agriculture regions. The objective of this study was to predict A horizon thickness and crop yield reduction under different soil conservation scenarios for the BSR during 2020 to 2200 to evaluate erosion hazard.

\section{METHOD}

\subsection{Study area}

The black soil region (BSR) is located in northeast China $\left(42^{\circ} 57^{\prime \sim} 50 \mathrm{deg} 14^{\prime} \mathrm{N}, 122 \mathrm{deg} 5^{\prime \sim} 128 \mathrm{deg} 12^{\prime} \mathrm{E}\right)$ and covers an area of $20.6^{*} 10^{4} \mathrm{~km}^{2}$ (Figure $4 \mathrm{~A}$ ). The BSR produces about $25 \%$ of China's corn. Related provinces 
include Heilongjiang, Jilin, Inner Mongolia and Liaoning. The climate is temperate and semi-humid monsoon climate, with a cold-dry winter and mild-wet summer. Mean annual precipitation ranges from $364 \mathrm{~mm}$ to 656 $\mathrm{mm}$ (Figure 4B). Mean annual temperature ranges from -0.5 to 7.1 . The topography is a quasi-basin, with elevation of 79 $776 \mathrm{~m}$ (Figure 4A). Geomorphology types include plain (56\%), table-land (36\%) and hill (8\%). The table-land is not flat, but rather undulating. According to genetic soil classification system of Chinese Soil Taxonomy, main soil great groups of the BSR include meadow soil $(36 \%)$, black soil $(26 \%)$, chernozem (22\%), dark-brown soil (5\%) and aeolian sand soil (5\%, Figure 4C). Meadow soils locate in the plain and valley bottom while black soils and chernozems mainly locate on the table-land. The original vegetation for black soils and chernozems were mainly steppe, with ground biomass of $1.1 \mathrm{~kg} / \mathrm{m}^{2}$ and underground biomass of $1.7 \mathrm{~kg} / \mathrm{m}^{2}$ (wet weight, CAS-FSI, 1980). Decomposition of the organic matter was historically rather slow due to the cold weather. As a result, most black soils and chernozems have fertile A horizons thicker than 30 $\mathrm{cm}$ and can be classified as mollisols in U.S. soil taxonomy (Figure 1). Parent materials are mainly loess and fluvial-lacustrine sediments. The difference between black soil and chernozem is that chernozem has calcium carbonates in the upper $100 \mathrm{~cm}$ due to its relatively drier climate. Dark-brown soils are mainly located in hill lands and classified as alfisols in U.S. soil taxonomy with parent materials of either slope deposits or residuum from granite and metamorphic rock. The BSR also includes Aeolians and soils which are deposits of wind eroded materials. Their clay content are less than $10 \%$ and SOM less than $0.5 \%$. They are mainly located in the western BSR, where the climate is drier and topography is mainly plains and gently sloping sand dunes. Some aeolian sands have an A horizon but are generally thinner than $15 \mathrm{~cm}$.

Nearing et al. (2017) provided a detailed description of the history of agricultural development in the BSR. Present landuse of the BSR is dominated by croplands $(69 \%$, Figure $4 \mathrm{D})$ that are only recently cultivated $\left(150\right.$ a). Sloping croplands cover an area of $7.2^{*} 10^{4} \mathrm{~km}^{2}$, with black soil, chernozem and dark-brown soil as the main soil types. Crops on sloping croplands are dominated by corn. The conventional tillage system is highly mechanized and includes moldboard ploughing, disking, ridging, harrowing and seeding in April, followed by fertilizing and spraying throughout the growing season, and harvesting in October. Ridge-furrow systems are common with $65^{\sim} 70 \mathrm{~cm}$ wide and $10 \mathrm{~cm}$ high ridges. China statistical yearbooks suggest mean corn yield per unit area is about $6500 \mathrm{~kg} / \mathrm{ha}$ in the BSR. The value was larger in south and smaller in north.

Water erosion (sheet-rill, ephemeral gully, gully) and wind erosion are all prevalent in the BSR. Runoff plot data indicates that sheet-rill erosion rate is $2^{\sim} 4 \mathrm{~mm} / \mathrm{a}$ on bare soils and $0.7 \mathrm{~mm} / \mathrm{a}$ on a $100 \mathrm{~m}$ long cropland (Liu et al., 2008). ${ }^{137} \mathrm{Cs}$ data indicates that mean sheet-rill erosion rates range from $1.2 \mathrm{~mm} / \mathrm{a}$ to $1.9 \mathrm{~mm} / \mathrm{a}$ on three small watersheds (Fang et al., 2005; Liu et al., 2008; Fang et al., 2012). A sheet-rill erosion rate as large as $4^{\sim} 7 \mathrm{~mm} / \mathrm{a}$ was reported for a $3 \mathrm{deg}^{\sim} 7 \mathrm{degslope}$ (CAS-FSI, 1980). Density of ephemeral gullies and classic gullies was $1.1 \mathrm{~km} / \mathrm{km}^{2}$ and $0.7 \mathrm{~km} / \mathrm{km}^{2}$ in typical small watersheds, respectively (Zhang et al., 2016). Soil erosion in the BSR can be significant because contour farming is rare, whereas, longitudinal ridge system (LRS), in which long straight rows oriented according to the parcel's borders, is the conventional tillage system in the BSR (Xu et al., 2018). Given that rows in the BSR tend to be extremely long with slope lengths that range from $200 \mathrm{~m}$ to $1000 \mathrm{~m}$ (Liu et al., 2011; Li et al., 2016), LRS involves undulating rows with sections inevitably aligned with the contour and other sections aligned more up and down slope. Thus, ridge directions are a combination of contour direction and up-down slope direction. The combination of the LRS on the undulating terrain inevitably results in significant slope gradients along furrows, which combined with long rows provides conditions for excessive erosion. Detachment of soils by water can be rather strong in these sloping furrows, especially in the long slope cases (Xu et al, 2018). Secondly, plant residue is rarely returned to soils. Straw is used as fuel or feed and remaining residue is generally burned in the field. Soils are essentially bare through winter until spring plant emergence during which time strong winds and storms often happened. Thirdly, high intensity mechanized tillage without subsoiling results in compacted layers for many croplands.

\subsection{Extraction of sloping cropland}

The GlobeLand30 dataset (30 m resolution, Chen et al., 2015) and the 1:1000000 geomorphologic atlas of the People's Republic of China (Cheng et al., 2011) was used to extract sloping croplands. Total area of 
sloping croplands was found to be $71641 \mathrm{~km}^{2}$.

\subsection{A horizon thickness}

A horizon thickness $\left(\mathrm{Th}_{A}\right)$ was derived from the soil species record (SSR) of each province (Soil Survey office of Heilongjiang province; 1990; Master Station of soil fertilizer of Liaoning province, 1991; Soil Survey office of Inner-Mongolia autonomous region, 1994; Master Station of soil fertilizer of Jilin province; 1997). SSR is a dataset describing soil species, including thickness, area and main soil properties (color, bulk density, SOM and particle size etc.) of each horizon. The SSRs were published in 1990s based on data collected in a national soil survey in 1980s. The BSR includes 15 great soil-groups, 58 sub soil-groups and 720 soil species. $\operatorname{Th}_{A}$ and area of each soil species were extracted from the SSR. The national 1:1000000 scale soil map was used for mapping. As the minimum mapping unit of the available soil map is sub soil-group (a level higher than soil species), $\mathrm{Th}_{A}$ of each sub soil-group was calculated by weighing $\mathrm{Th}_{A}$ of each soil species by area and then assigned to the corresponding polygon in the soil map. Extrapolation across scales can cause unintentional bias, as soil thickness and properties may change considerably over short distances (Hartemink et al., 2007) but is the best approach given the data limitations. As SSR data were mainly measured in1980s, theTh${ }_{A}$ in SSR was assumed to represent conditions in 1985. The $\mathrm{Th}_{A}$ in later years were calculated by subtracting eroded thickness from $\mathrm{Th}_{A}$ in 1985.

\subsection{Water erosion rate}

\subsubsection{Soil erosion model}

Only sheet-rill erosion was considered in this study and was based upon the China Soil Loss Equation (CSLE) which is similar to the USLE (Liu et al., 2002). The CSLE is:

$E_{r}=R K L S B E T(2)$

where ${ }_{r}$ is soil erosion rate (t/ha[?]a) and converted to a per area basis (mm/a) assuming a soil bulk density of $1.35 \mathrm{~g} / \mathrm{cm}^{3}$; R is mean annual rainfall erosivity (MJ.mm/ha.h); $\mathrm{K}$ is soil erodibility $\left(\mathrm{t} \cdot \mathrm{hm}^{2} \cdot \mathrm{h} / \mathrm{ha} \cdot \mathrm{MJ} \cdot \mathrm{mm}\right)$; L, S, B, E, and T are dimensionless factors of slope length, slope gradient, biological-control, engineeringcontrol, and tillage practices, respectively.

\subsubsection{Rainfall erosivity}

$\mathrm{R}$ was calculated from daily precipitation of 84 meteorological stations (1981 to 2010, China Meteorological Data Service Center) using an equation supplied by Xie et al. (2016). Daily precipitation lager than $12 \mathrm{~mm}$ was considered as erosive rainfall. $\mathrm{R}$ was calculated with following equations.

$R_{\text {day }}=\alpha \bullet P_{\text {day }}{ }^{1.7265}(3)$
$R_{\text {year }}=\sum R_{\text {day }}(4) R=R_{\text {year }}(5)$

where $R_{\text {day }}, R_{\text {year }}$ and $\mathrm{R}$ was rainfall erosivity of day, year, and mean annual rainfall erosivity, respectively, $\left(\mathrm{MJ}{ }^{*} \mathrm{~mm} / \mathrm{ha}{ }^{*} \mathrm{~h}\right) ; \alpha$ is a parameter that equals 0.3937 in the warm season (May-September) and 0.3101 in the cool season (October-April). The $\mathrm{R}$ values of all 84 stations were interpolated by Kriging.

\subsubsection{Soil erodibility}

SOM and particle size distributions of the A horizon of each soil species were extracted from SSR. Soil texture was determined by particle size distribution according to USDA standard. Soil-structure code and permeability class were determined by soil texture (Wischmeier and Smith, 1978; Wall et al., 2002). From these data, $K_{N}$ values were calculated with nomograph supplied by Wischmeier and Smith (1978). $\mathrm{K}_{\mathrm{N}}$ values were multiplied by a coefficient to derive $\mathrm{K}$ values, as runoff plot data showed that there is a deviation between $\mathrm{K}_{\mathrm{N}}$ and $\mathrm{K}$ for some soils in the BSR (Zhang et al., 2008). The coefficient was 0.14, 0.52, 0.82 and 0.80 for brown soil, dark-brown soil, albic soil and chernozem, respectively. The coefficient is 1 for other soils.

2.4.4 Slope gradient factor and slope length factor 
The $\mathrm{S}$ was calculated with the following equation:

$$
\begin{array}{lr}
\mathrm{S}=\{ \\
10.8 \sin \theta+0.03 & \theta<5 \\
16.8 \sin \theta-0.5 & 5 \leq \theta<10 \\
21.9 \sin \theta-0.96 & \theta \geq 10
\end{array}
$$

where $\theta$ is slope gradient $\left({ }^{\circ}\right)$. The shuttle radar topography mission (SRTM) data were used to calculate $\theta$. It is more difficult to calculate $\mathrm{L}$ than $\mathrm{S}$. It is impractical to measure the slope lengths for all croplands in BSR. The slope length of terrain $\left(\lambda_{T}\right)$ is rather long in the BSR, averaging $500 \sim 1000 \mathrm{~m}$. But $\lambda_{T}$ is not equivalent to the slope length of soil erosion $(\lambda)$. The $\lambda_{T}$ is often cut into smaller segments by features at cropland parcel boundaries in the BSR, such as windbreaks, roads and ditches, etc. Therefore, the $\lambda$ is very close to the topographic length of each cropland parcel $\left(\lambda_{P}\right)$. The $\lambda_{P}$ of 3218 cropland parcels in the BSR and Heilongjiang province were measured by Lv et al. (2013). The mean $\lambda_{P}$ was $260 \mathrm{~m}$ in table-land area and $152 \mathrm{~m}$ in hill area. These values were considered as $\lambda$ and used to calculate the slope length factor (L) with the following equation:

$L=\left(\frac{\lambda}{22.13}\right)^{m}(7)$

where $\mathrm{m}$ is the slope-length exponent. The value of $\mathrm{m}$ is related to slope gradient $(\theta)$. The $\mathrm{m}$ equals $0.2,0.3$, 0.4 and 0.5 , when $\theta$ range $<1^{\circ}, 1^{\sim} 3^{\circ}, 3^{\sim} 5^{\circ}$ and [?]3deg, respectively.

\subsubsection{Biological-control, engineering-control, and tillage practices}

Values of B, E and T were determined from runoff plot data and field surveys. B was set to 0.5 for croplands (Fan et al., 2011), and E set to 1, as engineering-control practices are very rare in the BSR. Because directions of ridge-furrow are mostly between contour and up-down slope in the BSR, T was assumed to be the mean value of $\mathrm{T}$ for contour farming $\left(\mathrm{T}_{\mathrm{C}}\right)$ and $\mathrm{T}$ for up-down slope farming (1). $\mathrm{T}_{\mathrm{C}}$ was calculated according to a regression equation based on data supplied by Wischmeier and Smith (1978).

$\mathrm{T}_{\mathrm{C}}=0.003 \theta^{2}-0.011 \theta+0.553 \mathrm{R}^{2}=0.92(8)$

2.5 Soil life expectancy, erosion hazard degree and relative crop yield

The SLE of A horizon $\left(\mathrm{SLE}_{\mathrm{A}}\right)$ was calculated with Equation (1), with $\mathrm{Th}_{\mathrm{CR}}$ as $20 \mathrm{~cm}$, based upon the initial thickness and the calculated ${ }_{r}$ from Equation (2), according to the flow chart in Figure 5. The erosion hazard degree was determined according to $\mathrm{SLE}_{\mathrm{A}}$ and the industry standard of China (Table 1, Ministry of Water Resources of China, 2008). The relative crop yield, ratio of future crop yield to current value, was calculated with $\mathrm{Th}_{A}$ and a regression function (Figure 2). The flow chart of calculation is shown in Figure 5. All data layers were in a $900 \mathrm{~m}^{2}$ resolution for calculation and analysis, including $\mathrm{Th}_{A}, \mathrm{R}, \mathrm{K}, \mathrm{L}, \mathrm{S}, \mathrm{B}, \mathrm{E}$, $\mathrm{T},{ }_{r}, \mathrm{SLE}_{\mathrm{A}}$ and relative crop yield etc. However, a $900 \mathrm{~m}^{2}$ resolution is too small for visualization in this article. Therefore, a resolution of $100 \mathrm{~km}^{2}$ is used for displaying results with the value of each $10^{*} 10 \mathrm{~km}$ grid being the mean value of all $30 * 30 \mathrm{~m}$ grids within it. The $100 \mathrm{~km}^{2}$ resolution is also the approximate size of townships in China, which is an administrative unit smaller than county.

\subsection{Soil conservation scenario}

To identify optimum soil conservation practices, the $\mathrm{SLE}_{\mathrm{A}}, \mathrm{Th}_{A}$ and relative crop yield were predicted under six soil conservation scenarios (Present, Contour, Straw, Combo 1, No-till and Combo 2) which cover major soil conservation practices in the BSR. Detailed description of each scenario was shown in Table 2. The tillage practice factor (T) value was derived from runoff plot data in the BSR (Yang, 2019) or in USLE handbook (Wischmeier and Smith, 1978). The relative crop yield was predicted with futureTh ${ }_{A}$ under each scenario and Equation (1). Residues were found to decrease soil temperature, emergence rate and crop yield in cool regions (Defelice et al., 2006). In the BSR, the intensity of this adverse effect varies spatially. In the southern (warmer) BSR, the effect of residue cover is negligible (Zhang et al., 2005; Gao et al., 2011), but in the northern (cooler) BSR, the adverse effect is significant. Compared to conventional tillage, corn yield can 
be reduced by $16 \%$ under No-till (Chen et al., 2011) and 11\% under Straw (Zou et al., 2016). These ratios were used to estimate future crop yield under Straw, No-till and Combo 2 in the cooler BSR areas, including Heilongjiang province and Inner Mongolia (Figure 4A). The relationships incorporated in the model for NT and Straw may not fully represent their effectiveness as the database may be skewed towards short term data. However, given the data available for the CSLE and crop yield response, the model predictions in this study reflect the best estimates currently available.

\section{RESULTS}

\subsection{Soil erosion rate $(\mathrm{r})$}

For validation, $r$ calculated for present conditions with the CSLE model (Equation 2) were compared with those measured by ${ }^{137} \mathrm{Cs}$ tracer method $(\mathrm{rCs})$ for the three BSR watersheds (Table 3). Each watershed was overlaid on the soil erosion rate map and mean $r$ was calculated. The mean ${ }_{\mathrm{rCs}}$ was $1.9 \mathrm{~mm} / \mathrm{a}$ in Fang et al. (2005), $1.6 \mathrm{~mm} / \mathrm{a}$ in Liu et al. (2008) and $1.2 \mathrm{~mm} / \mathrm{a}$ in Fang et al (2012), respectively (Table 3). Mean predicted $_{\mathrm{r}}$ was $1.8 \mathrm{~mm} / \mathrm{a}, 1.4 \mathrm{~mm} / \mathrm{a}$, and $1.2 \mathrm{~mm} / \mathrm{a}$, respectively. The ${ }_{\mathrm{r}}$ was very close to $\mathrm{rCs}_{\mathrm{s}}$ for all three watersheds validating the $\mathrm{r}$ predictions of this study at watershed scale.

Currently, the mean soil erosion rate $(\mathrm{r})$ across all the BSR was $0.90 \mathrm{~mm} / \mathrm{a}$. Distribution of $\mathrm{r}$ is positively skewed. About $70 \%$ of the sloping croplands had ${ }_{\mathrm{r} v a l u e s}$ below $1 \mathrm{~mm} / \mathrm{a}$, while $20 \%$ had $\mathrm{r}_{\mathrm{r}}$ values between 1 $\mathrm{mm} / \mathrm{a}$ and $2 \mathrm{~mm} / \mathrm{a}$. Only $11 \%$ of the sloping croplands had ${ }_{\mathrm{r}}$ values above $2 \mathrm{~mm} / \mathrm{a}_{\text {. The }} \mathrm{r}_{\mathrm{r}}$ was linearly and positively correlated with slope gradient (Figure 6). Townships with r above $2 \mathrm{~mm} /$ a were mainly located in the northwest counties and southeast counties, where landforms are dominated by hills (Figure 7). The relatively steeper landforms with more plentiful rainfall resulted in the larger erosion rates. Townships with $\mathrm{r}_{\mathrm{r}}$ between $1 \mathrm{~mm} / \mathrm{a}$ and $2 \mathrm{~mm} /$ a were mainly located in steeper table-lands dominated by black soil. Townships with $\mathrm{r}$ below $1 \mathrm{~mm} /$ a were mainly located in gentler table-lands, with mainly chernozem soils.

Mean $\mathrm{r}$ values, in descending order, were $0.90 \mathrm{~mm} / \mathrm{a}$ (Present), $0.79 \mathrm{~mm} / \mathrm{a}$ (Straw), $0.64 \mathrm{~mm} / \mathrm{a}$ (Contour), $0.39 \mathrm{~mm} / \mathrm{a}$ (Combo 1), $0.31 \mathrm{~mm} / \mathrm{a}$ (Combo 2) and $0.08 \mathrm{~mm} / \mathrm{a}$ (No-till, Figure 8). Compared to Present, $\mathrm{r}$ was reduced by $12 \%$ by Straw, $29 \%$ by Contour, $57 \%$ by Combo 1, $66 \%$ by Combo 2 and $91 \%$ by No-till. Notill was the most effective practice in reducing erosion. No-till can reduce erosion by $93 \%$ to $97 \%$, according to runoff plot studies in the BSR (Yang, 2019; Chen et al., 2019). The area of sloping croplands with $\mathrm{r}$ above $1 \mathrm{~mm} / \mathrm{a}$ under present conditions was $31 \%$ and fell to $26 \%$ under Straw, $17 \%$ under Contour and became negligible under Combo 1, Combo 2 and No-till. The areas with $\mathrm{r}_{\mathrm{r}}$ between $0.2 \mathrm{~mm} / \mathrm{a}$ and $1 \mathrm{~mm} / \mathrm{a}$ were rather close under Present, Straw, Contour, Combo 1, Combo 2, ranging from $49 \%$ to $62 \%$ but only $9 \%$ under No-till. The most significant difference was in sloping croplands with $\mathrm{r}$ below $0.2 \mathrm{~mm} / \mathrm{a}$. The area ratio was $11 \%$ under Present and increased to $15 \%$ under Straw, $21 \%$ under Contour, $34 \%$ under Combo 1, $48 \%$ under Combo 2, but leaped to $91 \%$ under No-till. It can be concluded that No-till is the most effective at saving A horizons, with Combo 2, Combo 1, Contour and Straw following in sequence.

\subsection{A horizon thickness}

Current $\mathrm{Th}_{A}$ averaged $31 \mathrm{~cm}$. The $\mathrm{Th}_{A}$ in early stage of cultivation was reported to be $35 \mathrm{~cm}$ to $59 \mathrm{~cm}$ with a mean of $44 \mathrm{~cm}$ (CAS-FSI, 1980). Thus, $13 \mathrm{~cm}$ of A horizon has been eroded since cultivation began $(\mathrm{r}[?] 1$ $\mathrm{mm} / \mathrm{a})$. The area ratio ofTh ${ }_{A}[?] 20 \mathrm{~cm}, 20<\mathrm{Th}_{A}[?] 30 \mathrm{~cm}, 30<\mathrm{Th}_{A}[?] 40 \mathrm{~cm}, 40<\mathrm{Th}_{A}[?] 50 \mathrm{~cm}$ and $\operatorname{Th}_{A} i 50 \mathrm{~cm}$ was $8.4 \%, 36.0 \%, 46.6 \%, 6.1 \%$, and $3.0 \%$, respectively. More than $80 \%$ of the croplands have $\mathrm{Th}_{A}$ between $20 \mathrm{~cm}$ and $40 \mathrm{~cm}$. $\mathrm{Th}_{A}$ was negatively correlated with $\theta$ (Figure 6). Townships with meanTh $\mathrm{Th}_{A}$ less than $20 \mathrm{~cm}$ were mainly located in the northwest counties (ML and AR etc.), where landforms are dominated by hills (Figure 9). The relatively thinner original A horizon and larger erosion rate in the northwest counties resulted in the $\operatorname{smallTh}_{A}$.

The area ratios of $\mathrm{Th}_{A}[?] 20 \mathrm{~cm}$ decreased under all scenarios (Figure 10). By 2200, the area ratios of $\mathrm{Th}_{A}[?] 20 \mathrm{~cm}$, in descending order, were $54 \%$ (Present), $50 \%$ (Straw), $42 \%$ (Contour), $33 \%$ (Combo 1), 32\% (Combo 2) and $12 \%$ (No-till). Croplands withTh ${ }_{A}[?] 20 \mathrm{~cm}$ are classified as "Damaged" in erosion hazard degree (Table 1). If the present situation was maintained, the ratio of "Damaged" will increase from the 
current $8 \%$ to $16 \%$ in $2050,29 \%$ in $2100,43 \%$ in 2150 and $54 \%$ in 2200 . Therefore, the present practices must be improved.

The area ratio of $20 \mathrm{~cm}[?] \mathrm{Th}_{A}<30 \mathrm{~cm}$ increased initially and then decreased under all conservation scenarios, expect for No-till (Figure 10). This pattern was due to the distribution of $\mathrm{Th}_{A}$. At first, the loss of croplands with $20 \mathrm{~cm}[?] \mathrm{Th}_{A}<30 \mathrm{~cm}$ was offset by the erosion of croplands with $\mathrm{Th}_{A}>30 \mathrm{~cm}$ being incorporated into this class. As the $>30 \mathrm{~cm}$ class became depleted, supplementing the $20-30 \mathrm{~cm}$ class could no longer offset the loss. No-till is an exception as the area ratio of $20 \mathrm{~cm}[?] \mathrm{Th}_{A}<30 \mathrm{~cm}$ kept on increasing under No-till at a rate of $0.3 \%$ per decade. This is because the erosion rate is very low and the offset can be sustainable. The area ratio of $30 \mathrm{~cm}[?] \mathrm{Th}_{A}<40 \mathrm{~cm}$ and $\mathrm{Th}_{A}>40 \mathrm{~cm}$ decreased under all scenarios. The decrease ratios were all below $0.5 \%$ per decade, with a minimum of $0.1 \%$ (No-till) and maximum of $0.4 \%$ (Present).

\subsection{Erosion hazard degree}

The area ratios presently for "Damaged", "High hazard", "Moderate hazard", "Low hazard" and "No hazard" were $8 \%, 5 \%, 22 \%, 61 \%$ and $4 \%$, respectively (Table 1). "Damaged" croplands were mainly located in northwest and southeast counties, with black soil and aeolian sand soil as the main soils (Figure 11). "High hazard" and "Moderate hazard" croplands were mainly located in northern counties with black soil and dark-brown soil as the main soils. "Low hazard" croplands were mainly located in eastern counties with black soil and chernozem as the main soils. "No hazard" croplands were mainly located in southern counties with chernozem and black soil as the main soils. Sadly, $8 \%$ of sloping croplands in the BSR are already damaged and $27 \%$ will be damaged in 100 a. Note that these are very conservative estimates as they account for sheet and rill erosion only and do not include gully erosion or wind erosion.

\subsection{Future corn yield}

The relative corn yield decreased under all soil conservation scenarios (Figure 12). The decrease rate under Straw was highest (1.3\% per decade). In this scenario, straws were shredded and incorporated into tillage layer $(20 \mathrm{~cm})$ in the fall. Incorporation of straw can provide some reduction in rill erosion by increasing the resistance of the soil to erosion (Van Liew and Saxton, 1983; Brown et al., 1989; Wei et al., 2013; Yang, 2019). However, incorporation in fall provides limited erosion protection during the winter and spring when erosion can be significant. According to Zou et al (2016), Straw can reduce the corn yield by $11 \%$. This ratio will increase to $16 \%$ if the tillage layer is $15 \mathrm{~cm}$ thick. The reduced but still rather high erosion rate under Straw $(0.79 \mathrm{~mm} / \mathrm{a})$, together with its adverse effect on crop yield, results in the largest decrease rate of crop yield among all scenarios. By 2200 , the corn yield will be $77 \%$ of current value. The decrease in crop yield under Present ranked second highest (0.8\% per decade). By 2200 , the corn yield will be $85 \%$ of current value. Nearing et al. (2017) recognized the problem as being the use of conventional tillage with long rows and concluded that "unless major changes are made to tillage and management (residue) practices" the land will not remain under production. This study places time-frames on the soil life expectancy and spatial distributions of the degree of soil erosion hazard to assess the effectiveness of different conservation practices.

Despite the effectiveness of no-till at controlling erosion, the yield decrease under No-till ranked third highest. The corn yield abruptly decreased to $88 \%$ of present after application of No-till. Nearing et al. (2017) acknowledged that no-till does not work well in all environments and can have limitations when soil moisture or soil temperature becomes an issue. No-till was found to decrease corn yield by $15.7 \%$ on sloping croplands in the cold BSR by Chen et al. (2011) and $26.8 \%$ by Zou et al. (2016). Negative effects of no-till on crop yield are also reported in similar cold regions, such northern America and Canada (Defelice et al., 2006). In cooler BSR, the mean soil temperature at $20 \mathrm{~cm}$ depth in May is mostly below 12, with minimum below 8

(Figure 4B). In contrast, the mean value was mostly above 12 in warmer BSR, with maximum above 15 . Studies in warmer BSR areas (Figure 4) indicate that no-till can slightly increase corn yield (Zhang et al., 2010; Zhou et al., 2015). Thus, the cause of the abrupt yield decrease predicted in this study for no-till is likely an issue with the low soil temperatures in the BSR.

The corn yield decrease rate under Contour, Combo 1 and Combo 2 ranked fourth, fifth and sixth, re- 
spectively. By 2200, crop yield decrease was only $4 \%$ under Combo 1 and Combo 2. Xu et al. (2018) recommended flat tillage systems for the BSR because in laboratory test it exhibited lower runoff and soil loss than ridge systems whether on contour or up and down slopes. An alternative that may improve the performance of conventionally tilled ridge systems is the use of furrow dikes which are essentially small check dams at intervals along the furrows. Strip tillage, in which residue is maintained on the top of rows (typically with flat tillage but can apply to ridge systems), shows great potential for erosion control (Licht and Al-Kaisi, 2005; Shi and Mi, 2018). However, none of these systems have sufficient in situ experimental data on erosion and crop yield in the BSR to be included in this analysis.

\subsection{Optimum soil conservation practice}

For "Damaged" croplands, current soils not only need to be saved but also improved. No-till with residue management is the optimum practice, as it can both reduce erosion and increase fertility. For those located in north BSR where no-till is less productive, manures could be used to offset residue removal and restore fertility (Singer et al., 2004). For those with aeolian sand soils, soil amendments, such as winter cover crops, manures, peat (Li et al., 2004) and biochar (Uzoma et al., 2001; Bruun et al., 2014) could improve soil structure and fertility. For "High hazard" croplands, conservation practices should be applied as soon as possible, as A horizons will all become thinner than $20 \mathrm{~cm}$ in just 20 years. These croplands are a priority in conservation planning. Contour farming is not recommended for them, as it only slightly increases the $\mathrm{SLE}_{\mathrm{A}}$ (Table 4). The reason is that "High hazard" croplands are mainly distributed on steeper areas, where contour farming has limited effectiveness. Contour farming can only reduce erosion by $43 \%$ on a $5^{\circ}$ slope and by $26 \%$ on a $10^{\circ}$ slope. In contrast, Combo 1 , Combo 2 and No-till can all increase the $\mathrm{SLE}_{\mathrm{A}}$ to more than 100 a. These practices are recommended. Among them, Combo 2 may be the optimum practice. Compared to Combo 1, Combo 2 is less costly as less terracing is needed. Compared to No-till, Combo 1 is more productive. For "Moderate hazard" croplands, practices should be applied before 2040 to keep A horizons thicker than $20 \mathrm{~cm}$. No-till is not recommended even though it can increase $\mathrm{SLE}_{\mathrm{A}}$ to more than 3000 a since most "Moderate hazard" croplands are located in the north BSR where no-till is less productive. For, "Low hazard" and "No hazard" croplands, present practices are acceptable although they should be used with care to maintain soil health. However, additional practices are necessary if erosion types other than sheet-rill erosion are prevalent or a better crop yield is desired.

\subsection{Optimum conservation schedule}

An optimum conservation schedule is proposed with the following principles. The plan is spatially precise so that it can tell where to act. The spatial resolution used here is $100 \mathrm{~km}^{2}$, which is approximately the size of townships. The plan is temporally precise so that it can tell when to act to make sure all soils have $\mathrm{Th}_{A}$ maintained above $20 \mathrm{~cm}$. In our schedule, practices are applied immediately for the "Damaged" and "High hazard", before 2040 for the "Moderate hazard", before 2120 for the "Low hazard" and no changes applied to the "No hazard" areas. The start year for action depends on the township's maximum erosion hazard degree. Sequential actions by township will reduce workload for related people in other counties and earlieracting townships will provide training for later-acting townships. Based on these principles, an optimum conservation schedule is suggested (Figure13). About $46 \%$ of townships should act immediately, while $17 \%$ should act before 2040. Due to logistic, economic, social and other reasons, this schedule is an idealized one that can serve as a target/goal for government officials and land managers. However, the following alarm must be sounded, $180 \mathrm{~km}^{2}$ croplands will become "Damaged" and at least $0.8 \%$ of corn yield lost irreversibly with every 10 year delay.

\section{CONCLUSIONS}

A strategy to evaluate soil erosion hazard degree and soil conservation planning for agriculture regions of the BSR of China has been proposed. The innovative aspect of this strategy is the combination of the known relationship between A horizon thickness and crop yield for the BSR with a soil erosion model that bases predictions upon the spatial distribution of the current A horizon thickness and soil properties by soil types. Erosion hazard degree and relative crop yield under different soil conservation scenarios including current 
tillage (conventional tillage), contour tillage, straw incorporated tillage, no-till farming and two combinations of terracing and "green for grain" practices were evaluated. Knowing that an A horizon thickness of $20 \mathrm{~cm}$ is the critical threshold for crop productivity, a soil life expectancy was calculated. Croplands with soil life expectancies of $<0$ a, 0 a 20 a, 20 a 100 a, 100 a 1000 a and [?]1000 a, were classified as "Damaged", "High hazard", "Moderate hazard", "Low hazard" and "No hazard", respectively.

The soil erosion model was validated from ${ }^{137}$ Cs erosion rate measurements for three watersheds of the BSR. The spatial distribution in soil erosion rates for the BSR was linearly and positively correlated with slope gradient and dependent upon the conservation practice scenario. The current tillage practice exhibited the highest soil erosion rates while no-tillage had the lowest soil losses. On average, about $13 \mathrm{~cm}$ of A horizon has been eroded away since the establishment of cultivation. Across the BSR, $8 \%$ of the sloping croplands are already classified as Damaged which will increase to $27 \%$ within 100 years under current practices. The corn yield decreased very fast (0.8\% per decade) under the current tillage practice. Despite the effectiveness of no-till to control erosion, this was the third highest practice tested for loss in crop yield due to issues in applying no-till farming in cold regions. The best practice for High hazard, Moderate hazard and Low hazard was Combo 2, applying no-till, contour farming terraces and "green for grain" practices according to the slope gradient and regional temperature (cool or warm). For "High hazard" croplands, conservation practices should be applied immediately as these areas will convert to "Damaged" in just 20 years under current practices. Future research should include other management strategies, such as winter cover crops, strip tillage for flat and ridge system, furrow dikes made from soil or possibly cornstalks, or flat tillage. Such management options could be incorporated into the model predictions of erosion hazard and crop yield once the relationships are experimentally established.

A scheme for optimum spatially and temporally distributed scheduling of soil conservation practices is presented. The plan is designed to maintain all soils to have an A horizon above $20 \mathrm{~cm}$ by selecting and scheduling the implementation of conservation practices according to their degree of hazard. Scheduling the implementation of conservation practices according to the township's maximum erosion hazard will optimize the distribution of labor and serve as a training tool for later-acting townships. Soil erosion estimates are conservative, and as such the soil life expectancy estimates are under-predicted due to not considering gully and wind erosion processes. This study quantifies the urgency in taking action to apply conservation methods in the BSR in order to sustain agriculture while maintaining soil health.

\section{ACKNOWLEDGEMENTS}

This work was supported by National Key Research and Development Program of China (No. 2018YFC0507005, No. 2016YFA0602301) and National Natural Science Foundation of China (No. 41401304; No. 41571526). We thank staff of Jiusan soil and water conservation experimental station of Beijing Normal University, Prof. Hongyan Zhang and Dr. Yanfang Hao for data collection, Dr. Zhongqiang Wang for comments. The authors indicate no potential conflicts of interest.

\section{REFERENCES}

1. Ball-coelho, B. R., Roy, R. C., \& Swanton, C. J. (1998). Tillage alters corn root distribution in coarse-textured soil. Soil and Tillage Research, 45(3), 237-249.

2. Benaud, P., Anderson, K., Evans, M., Farrow, L., Glendell, M., James, M. R., .. Brazier, R. E. (2020). National-scale geodata describe widespread accelerated soil erosion. Geoderma, 371, 114378.

3. Brown, L. C., Foster, G. R., \& Beasley, D. B. (1989). Rill erosion as affected by incorporated crop residue and seasonal consolidation. Transactions of the ASAE, 32(6), 1967-1978.

4. Bruun, E. W., Petersen, C. T., Hansen, E., Holm, J. K., \& Hauggaard-Nielsen, H. (2014). Biochar amendment to coarse sandy subsoil improves root growth and increases water retention. Soil Use and Management, 30(1), 109-118.

5. Cannell, R. Q., Belford, R. K., Blackwell, P. S., Govi, G., \& Thomson, R. J. (1985). Effects of waterlogging on soil aeration and on root and shoot growth and yield of winter oats (Avena sativa L.). Plant and Soil, 85(3), 361-373. 
6. CAS-FSI. (1980). Northeast China soil, Science Press, Beijing, pp. 127 (in Chinese).

7. Chen, J., Chen, J., Liao, A., Cao, X., Chen, L., Chen, X., .. \& \& Zhang, W. (2015). Global land cover mapping at $30 \mathrm{~m}$ resolution: A POK-based operational approach. ISPRS Journal of Photogrammetry and Remote Sensing, 103, 7-27.

8. Chen, S., Burras, C. L., E, L., \& Zhang, X. (2019). Interrelationship among slope steepness, tillage practice and rainfall properties with surface runoff and soil loss on Mollisols in Northeast China. Archives of Agronomy and Soil Science, 65(13), 1860-1872.

9. Chen, Y., Liu, S., Li, H., Li, X. F., Song, C. Y., Cruse, R. M., \& Zhang, X. Y. (2011). Effects of conservation tillage on corn and soybean yield in the humid continental climate region of northeast China. Soil and Tillage Research, 115, 56-61.

10. Cheng, W., Zhou, C., Chai, H., Zhao, S., Liu, H., \& Zhou, Z. (2011). Research and compilation of the Geomorphologic Atlas of the People's Republic of China (1: 1,000,000). Journal of Geographical Sciences, 21(1), 89-100.

11. DeFelice, M. S., Carter, P. R., \& Mitchell, S. B. (2006). Influence of tillage on corn and soybean yield in the United States and Canada. Crop Management.doi:10.1094/CM-2006-0626-01-RS.

12. Fan, J., McConkey, B. G., Wang, H., \& Janzen, H. H. (2016). Root distribution by depth for temperate agricultural crops. Field Crops Research, 189, 68-74.

13. Fan, J., Wang, N., Chen, G., Jiao, J., \& Xie, Y. (2011). Practice factor of soil and water conservation in northeastern China. Science of Soil and Water Conservation, 9(3), 75-78. (in Chinese)

14. Fang, H., Sun, L., Qi, D., \& Cai, Q. (2012). Using ${ }^{137}$ Cs technique to quantify soil erosion and deposition rates in an agricultural catchment in the black soil region, Northeast China. Geomorphology, 169, 142150.

15. Fang, H., Yang, X., Zhang, X., \& Liang, A. (2005). Redistribution patterns of black soil in hillslope landform of northeast china: $\mathrm{a}^{137} \mathrm{Cs}$ study. Chinese Journal of Applied Ecology, 16(3), 464-468. (in Chinese)

16. Feng, Z., Zheng, F., Hu, W., Li, G., \& Xu, X. (2018). Impacts of mollic epipedon thickness and overloaded sediment deposition on corn yield in the Chinese Mollisol region. Agriculture, Ecosystems and Environment, 257, 175-182.

17. Fenton, T. E., Kazemi, M. T., \& Lauter-bachbarrett, M. A. (2005). Erosional impact on organic matter content and productivity of selected Iowa soils. Soil and Tillage Research, 81(2), 163-171.

18. Gao, H., Peng, C., Zhang, X., Li, Q., Zhu, P., \& Fu, J. (2011). Effects of long-term straw returning field on the carbon and nitrogen in black soil and maize yield. Journal of Maize Sciences 19(6), 105-107. (in Chinese)

19. Hartemink, A. E., Gennadiyev, A. N., Bockheim, J. G., \& Bero, N. (2017). Short-range variation in a Wisconsin soilscape (USA). Eurasian Soil Science, 50(2), 198-209.

20. Li, G., Zheng, F., Lu, J., Xu, X., Hu, W., \& Han, Y. (2016). Inflow rate impact on hillslope erosion processes and flow hydrodynamics. Soil Science Society of America Journal, 80(3), 711-719.

21. Li, H., Parent, L. E., Karam, A., \& Tremblay, C. (2004). Potential of Sphagnum peat for improving soil organic matter, water holding capacity, bulk density and potato yield in a sandy soil. Plant and Soil, 265(1-2), 355-365.

22. Licht, M. A., \& Al-Kaisi, M. (2005). Strip-tillage effect on seedbed soil temperature and other soil physical properties. Soil and Tillage Research 80(1-2), 233-249.

23. Liu, B., Zhang, K., \& Xie, Y. (2002). An empirical soil loss equation, 12th ISCO Conference.

24. Liu, B., Yan, B., Shen, B, Wang, Z., \& Wei, X. (2008). Current status and comprehensive control strategies of soil erosion for cultivated land in the northeastern black soil area of China. Science of Soil and Water Conservation, 6(1), 1-8.

25. Liu, H., Zhang, T., Liu, B., Liu, G., \& Wilson, G. V. (2013). Effects of gully erosion and gully filling on soil depth and crop production in the black soil region, northeast China. Environmental Earth Sciences, 68(6), 1723-1732.

26. Liu, X., Zhang, S., Zhang, X., Ding, G., \& Cruse, R. M. (2011). Soil erosion control practices in Northeast China: A mini-review. Soil and Tillage Research, 117, 44-48. 
27. Lv. Z., Liu, F., \& Sun X., (2013). Research on minimum erosion slope gradient of sloping cropland in hilly region of Heilongjiang province. Applied Technology of Soil and Water Conservation, 6, 8-9. (in Chinese)

28. Master Station of Soil Fertilizer of Liaoning Province. (1991). Soil Species of Liaoning. Shenyang: Liaoning University Press. (in Chinese)

29. Master Station of Soil Fertilizer of Jilin Province. (1997). Soil species of Jilin. Changchun: Jilin Science and Technology Press. (in Chinese)

30. Ministry of Water Resources of China. (2008). Standards for classification and gradation of soil erosion (SL190-2007). (in Chinese)

31. National Soil Erosion-Soil Productivity Research Planning Committee (NSESPRPC). (1981). Soil erosion effects on soil productivity: a research perspective. Journal of Soil and Water Conservation, $36,82-90$.

32. Nearing, M.A., Xie, Y., Liu, B., \& Ye, Y. (2017). Natural and anthropogenic rates of soil erosion. International Soil and Water Conservation Research, 5, 77-84.

33. Paroissien, J., Darboux, F., Couturier, A., Devillers, B., Mouillot, F., Raclot, D., \& Bissonnais, Y. L. (2015). A method for modeling the effects of climate and land use changes on erosion and sustainability of soil in a Mediterranean watershed (Languedoc, France). Journal of Environmental Management, 150, 57-68.

34. Shi, D., \& Mi, G. (2018). Straw mulching strip-till technology and its application in corn production. Soils and Crops, 7(3), 349-355. (in Chinese).

35. Singer, J. W., Kohler, K. A., Liebman, M., Richard, T. L., Cambardella, C. A., \& Buhler, D. D. (2004). Tillage and compost affect yield of corn, soybean, and wheat and soil fertility. Agronomy Journal 96(2), 531-537.

36. Soil Survey Office of Heilongjiang Province. (1990). Soil species of Heilongjiang. (in Chinese)

37. Soil Survey Office of Inner-Mongolia Autonomous Region, \& Station of Soil Fertilizer of Inner Mongolia Autonomous Region. (1994). Soil Species of Inner Mongolia of China. Beijing: China Agriculture Press (in Chinese).

38. Sparovek, G., \& Schnug, E. (2001). Temporal erosion-induced soil degradation and yield loss. Soil Science Society of America Journal, 65(5), 1479-1486.

39. Sui, Y., Liu, X., Jin, J., Zhang, S., Zhang, X., Herbert, S. J., \& Ding, G. (2009). Differentiating the early impacts of topsoil removal and soil amendments on crop performance/productivity of corn and soybean in eroded farmland of Chinese Mollisols. Field Crops Research, 111(3), 276-283.

40. Uzoma, K. C., Inoue, M., Andry, H., Fujimaki, H., Zahoor, A., \& Nishihara, E. (2011). Effect of cow manure biochar on maize productivity under sandy soil condition. Soil Use and Management, 27(2), 205-212.

41. Van Liew, M. W., \& Saxton, K. E. (1983). Slope steepness and incorporated residue effects. Transactions of the ASAE, 26(6), 1738-1743.

42. Wall, G. J., Coote, D. R., Pringle, E. A., \& Shelton, I. J. (1997). RUSLEFAC-revised universal soil loss equation for application in Canada. Centre for land and biological resources research, research branch, agriculture and agri-food, Ottawa, Canada.

43. Wang, S., Huang, Y., Sun, W., \& Yu, L. (2018). Mapping the vertical distribution of maize roots in China in relation to climate and soil texture. Journal of Plant Ecology, 11(6), 899-908.

44. Wei, Y., Li, X., \& Hu, T. (2013). Soil and water conservation and water-saving and soybean yield increasing effects of different conservation tillage technology modes in sloping farmland. Journal of Northeast Agricultural University, 44(5), 51-55. (in Chinese)

45. Wen, F. H., \& Easter, K. W. (1987). Erosion and the loss of soil productivity on the Terril soil series in Minnesota. Economic Reports.

46. Wischmeier, W. H., \& Smith, D. D. (1978). Predicting rainfall erosion losses: a guide to conservation planning (No. 537). Department of Agriculture, Science and Education Administration.

47. Xie, Y., Yin, S., Liu, B., Nearing, M. A., \& Zhao, Y. (2016). Models for estimating daily rainfall erosivity in China. Journal of Hydrology, 535, 547-558. 
48. Xu, X., Zheng, F., Wilson, G.V., He, C., Lu, J., \& Bian, F. (2018). Comparison of runoff and soil loss in different tillage systems in the Mollisol region of Northeast China. Soil and Tillage Research, $177,1-11$.

49. Yang, X. (2019). Soil erosion factors calculated by runoff plot data. Master Degree Dissertation, Beijing: Beijing Normal University.

50. Zhang, B., He, H., \& Zhao, X. (2010). Effects of crop-residue incorporation on no-tillage soil available nutrients and corn yield. Journal of Maize Sciences 18(2), 81-84. (in Chinese)

51. Zhang, K., Shu, A., Xu, X., Yang, Q., \& Yu, B. (2008). Soil erodibility and its estimation for agricultural soils in China. Journal of Arid Environments, 72(6), 1002-1011.

52. Zhang, T., Liu, G., Duan, X., \& Wilson, G. V. (2016). Spatial distribution and morphologic characteristics of gullies in the Black Soil Region of Northeast China: Hebei watershed. Physical Geography, $37(3-4), 228-250$.

53. Zhang, X., Liu, X., Sui, Y., Zhang, X. Zhang, J., Liu, H., \& Herbert, S. J. (2006). Effects of artificial topsoil removal on soybean dry matter accumulation and yield in Chinese Mollisols. Soybean Science 25(2), 123-126. (in Chinese)

54. Zhang, X., Yang, X., Fang, H., \& Liang, A. (2005). Effects of tillage on corn and soybean yields in middle layer black soil of northeast China. Journal of Jilin Agricultural University 27 (4), 429-433. (in Chinese)

55. Zhou, G., Zhang, X., Liang, R., Liang, A., Huang, D., \& Yang, X. (2015). No-tillage effects on corn and soybean yield and profitability: based on a long-term field trial of black soil in northeast China. Journal of Jilin Agricultural University, 37(3), 260-267. (in Chinese)

56. Zou, W., Lu, X., Han, X., \& Wang, F., (2016). The impact of tillage depth and straw incorporation on crop yield andsoil water supply in arable black soil. Soils and Crops, 5(3), 141-149. (in Chinese)

\section{Hosted file}

TABLE 1.docx available at https://authorea.com/users/318699/articles/449392-erosion-hazardevaluation-for-soil-conservation-planning-that-sustains-life-expectancy-of-a-horizonthe-black-soil-region-of-china

\section{Hosted file}

TABLE 2.docx available at https://authorea.com/users/318699/articles/449392-erosion-hazardevaluation-for-soil-conservation-planning-that-sustains-life-expectancy-of-a-horizonthe-black-soil-region-of-china

\section{Hosted file}

TABLE 3.docx available at https://authorea.com/users/318699/articles/449392-erosion-hazardevaluation-for-soil-conservation-planning-that-sustains-life-expectancy-of-a-horizonthe-black-soil-region-of-china

\section{Hosted file}

TABLE 4.docx available at https://authorea.com/users/318699/articles/449392-erosion-hazardevaluation-for-soil-conservation-planning-that-sustains-life-expectancy-of-a-horizonthe-black-soil-region-of-china 

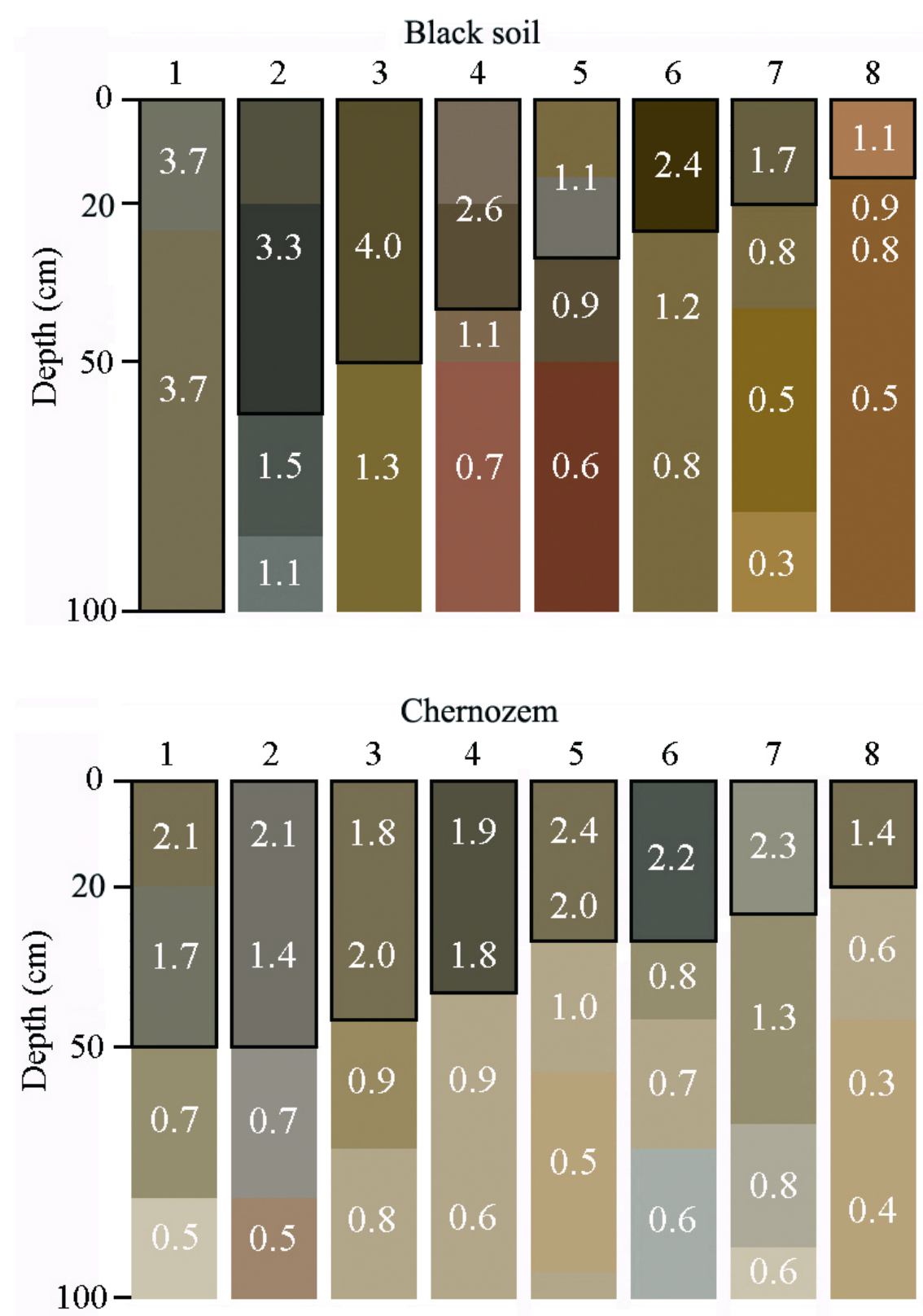

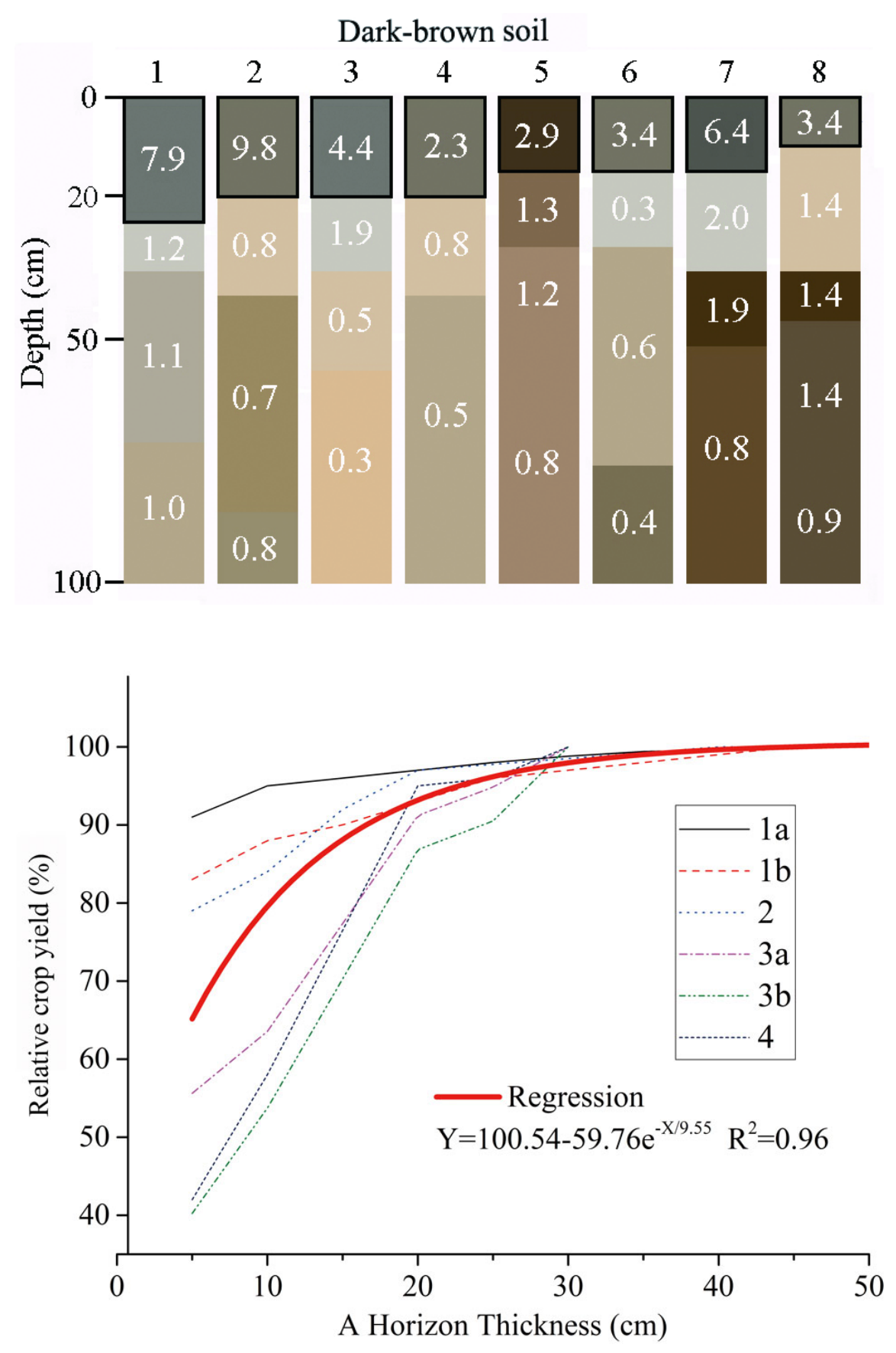

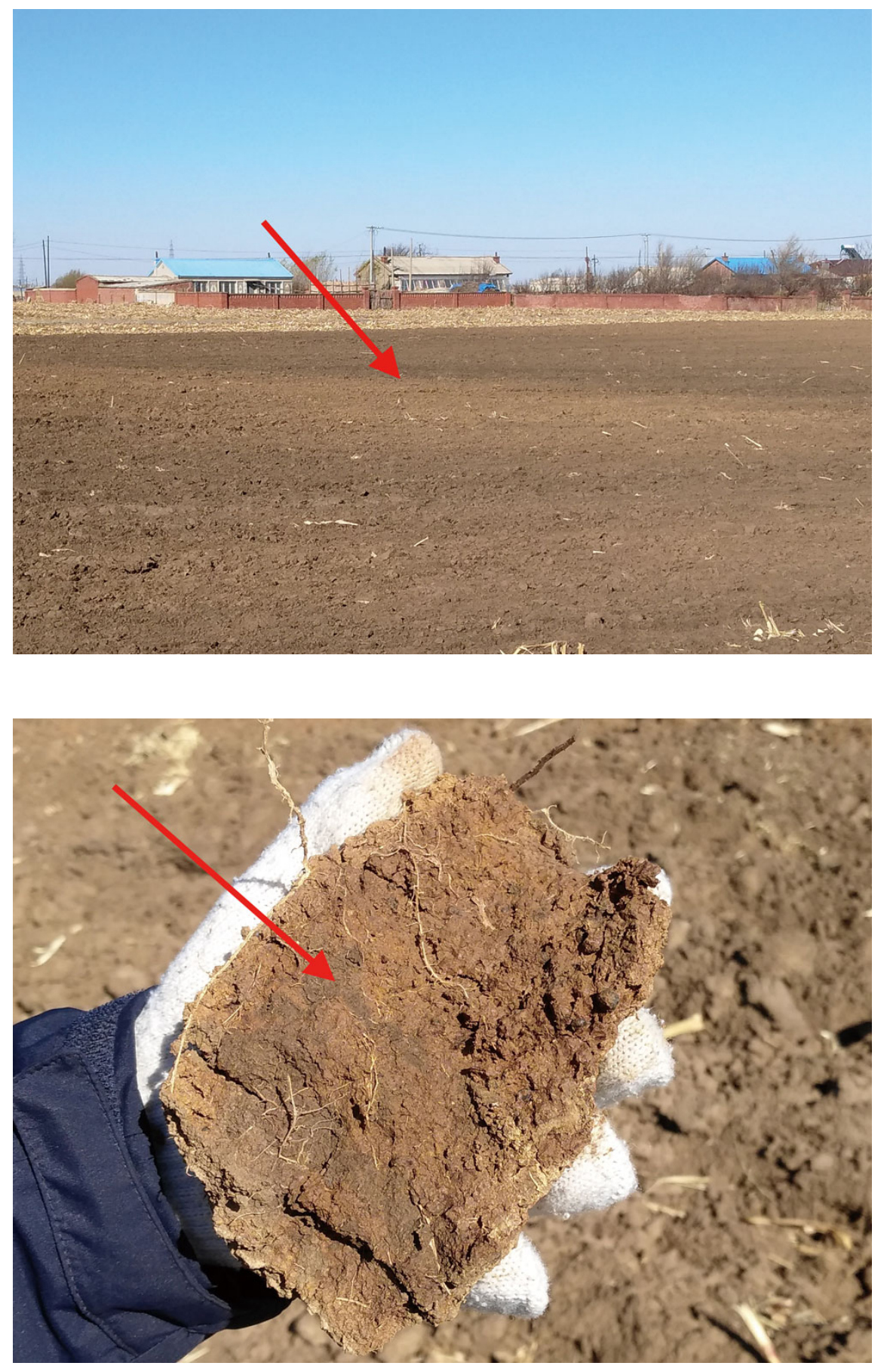


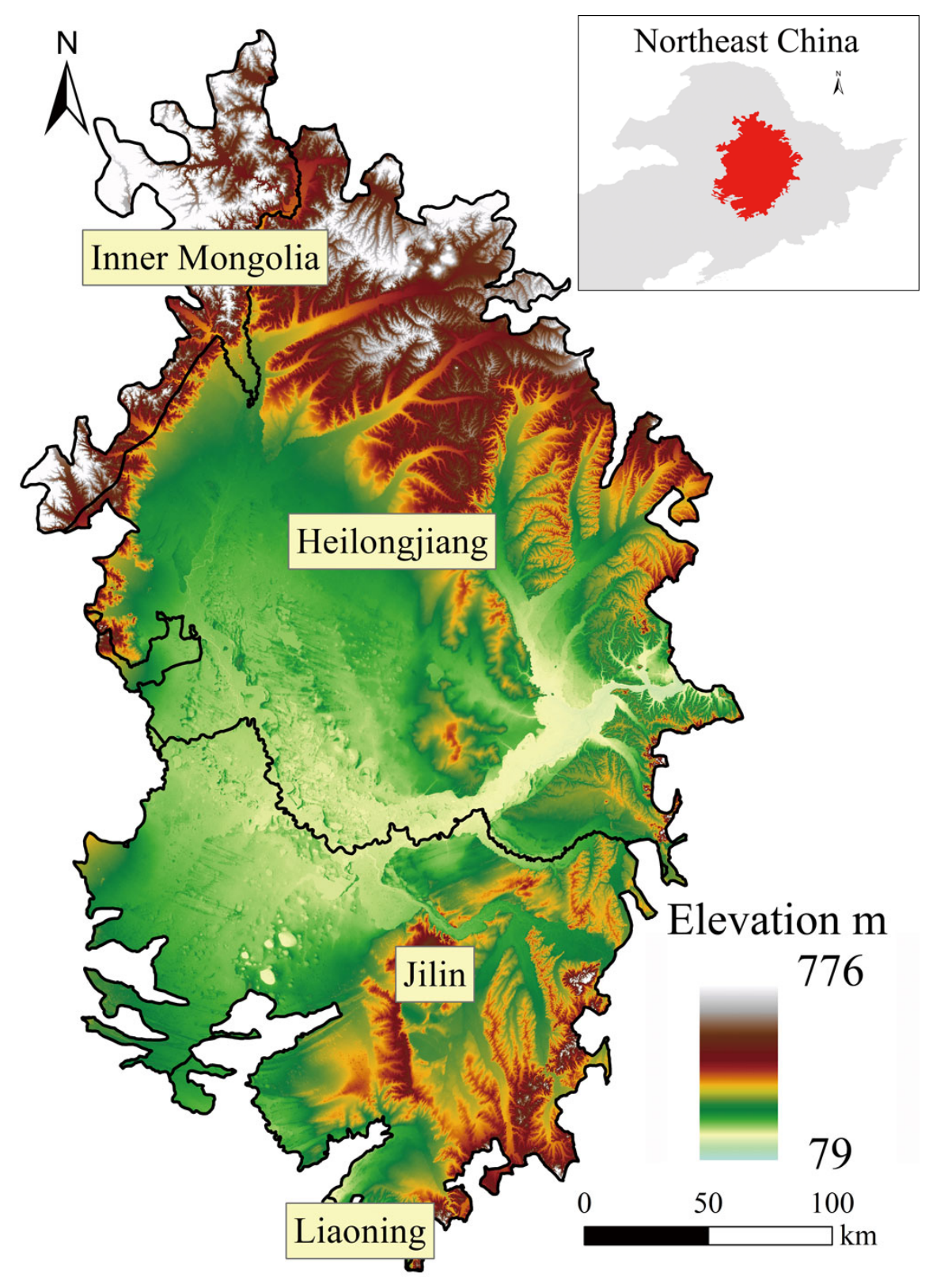




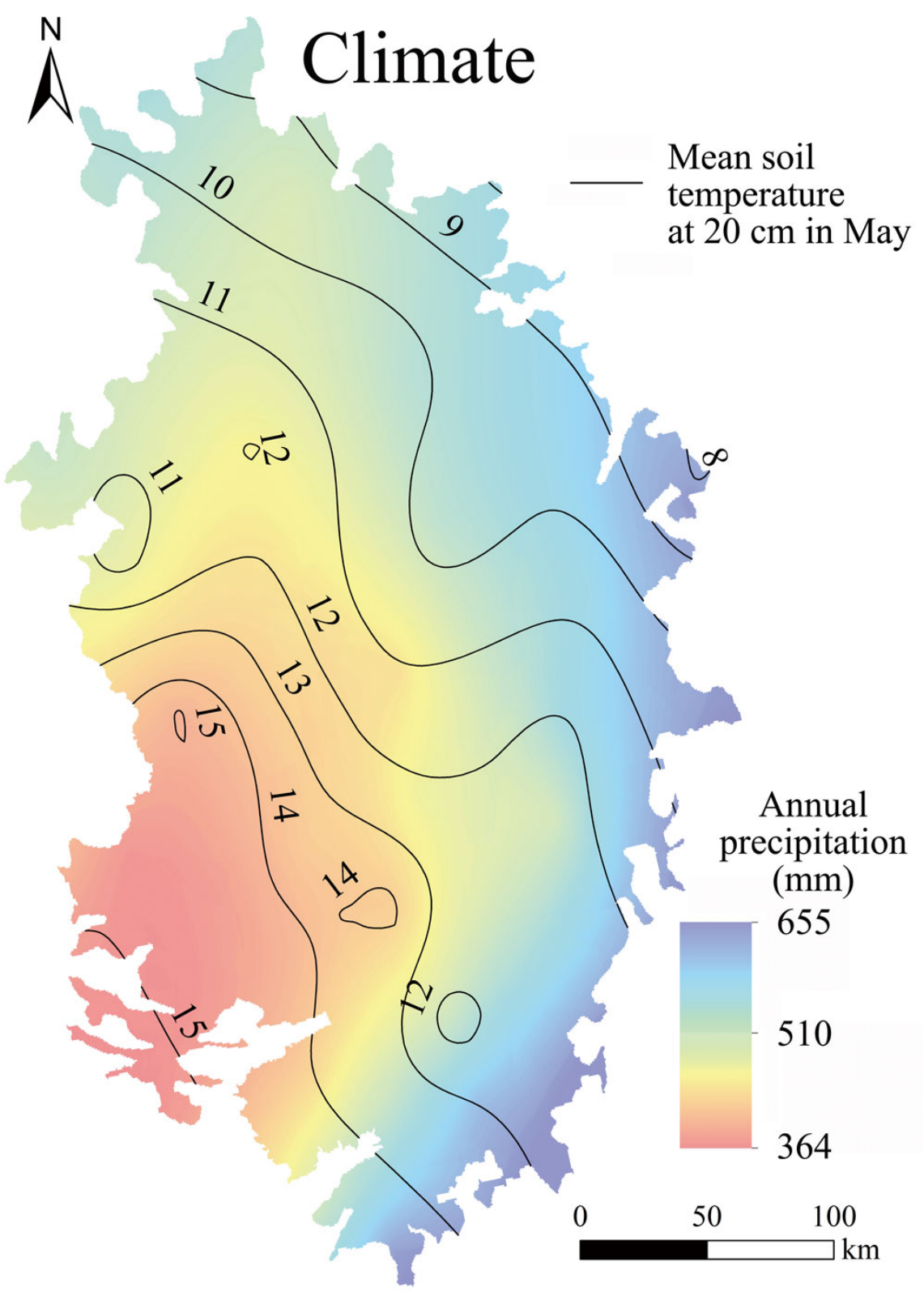




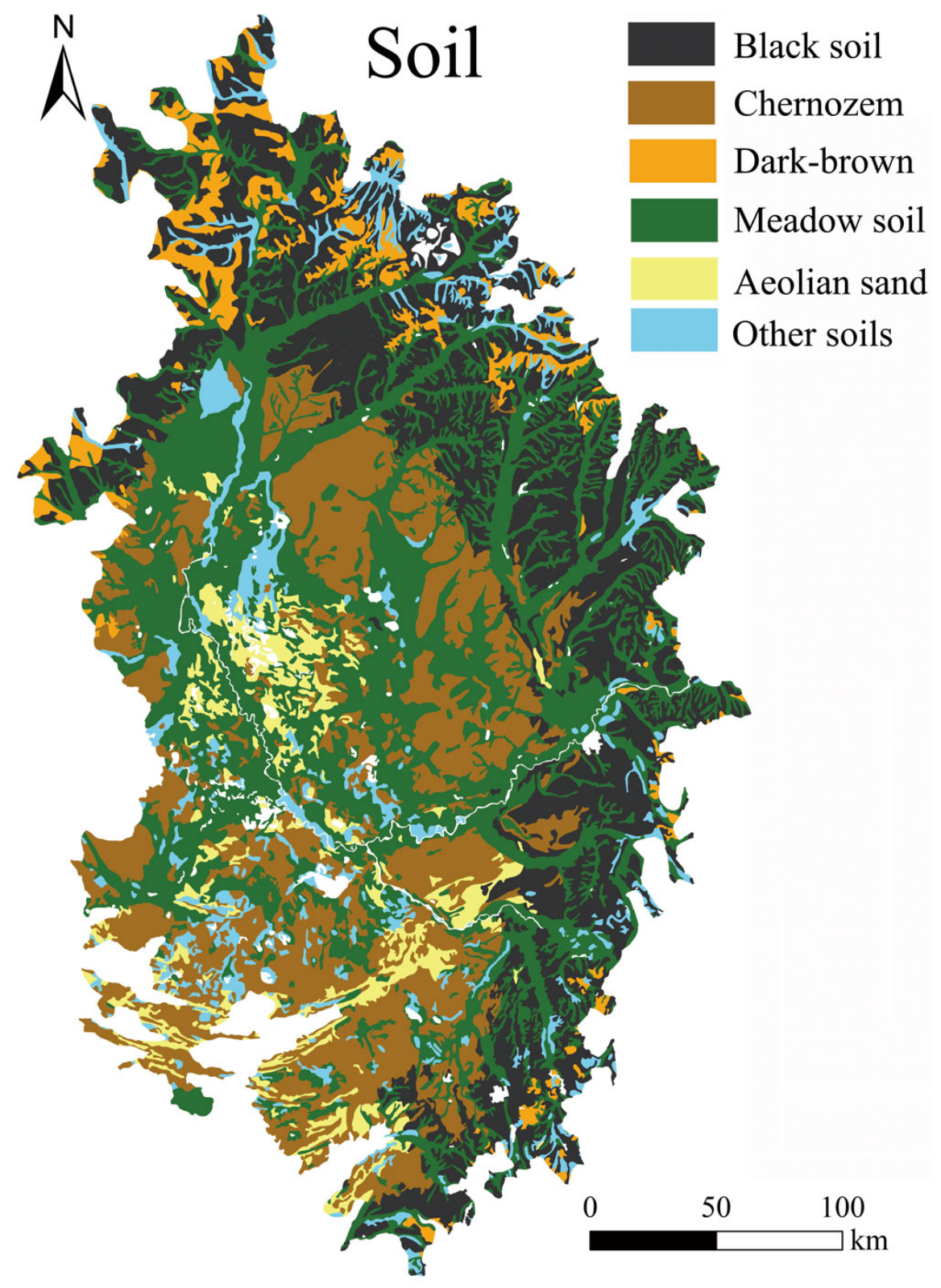




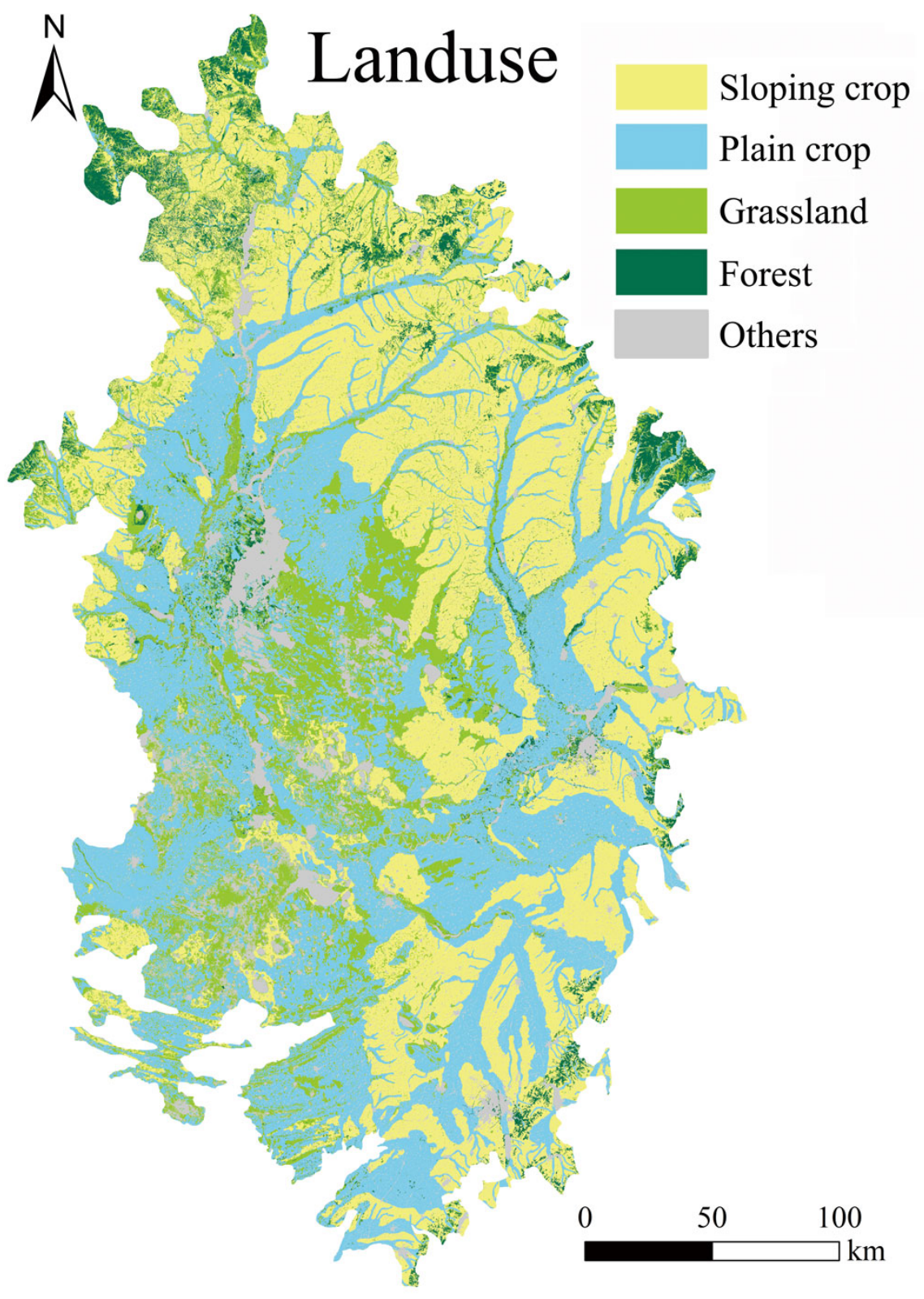



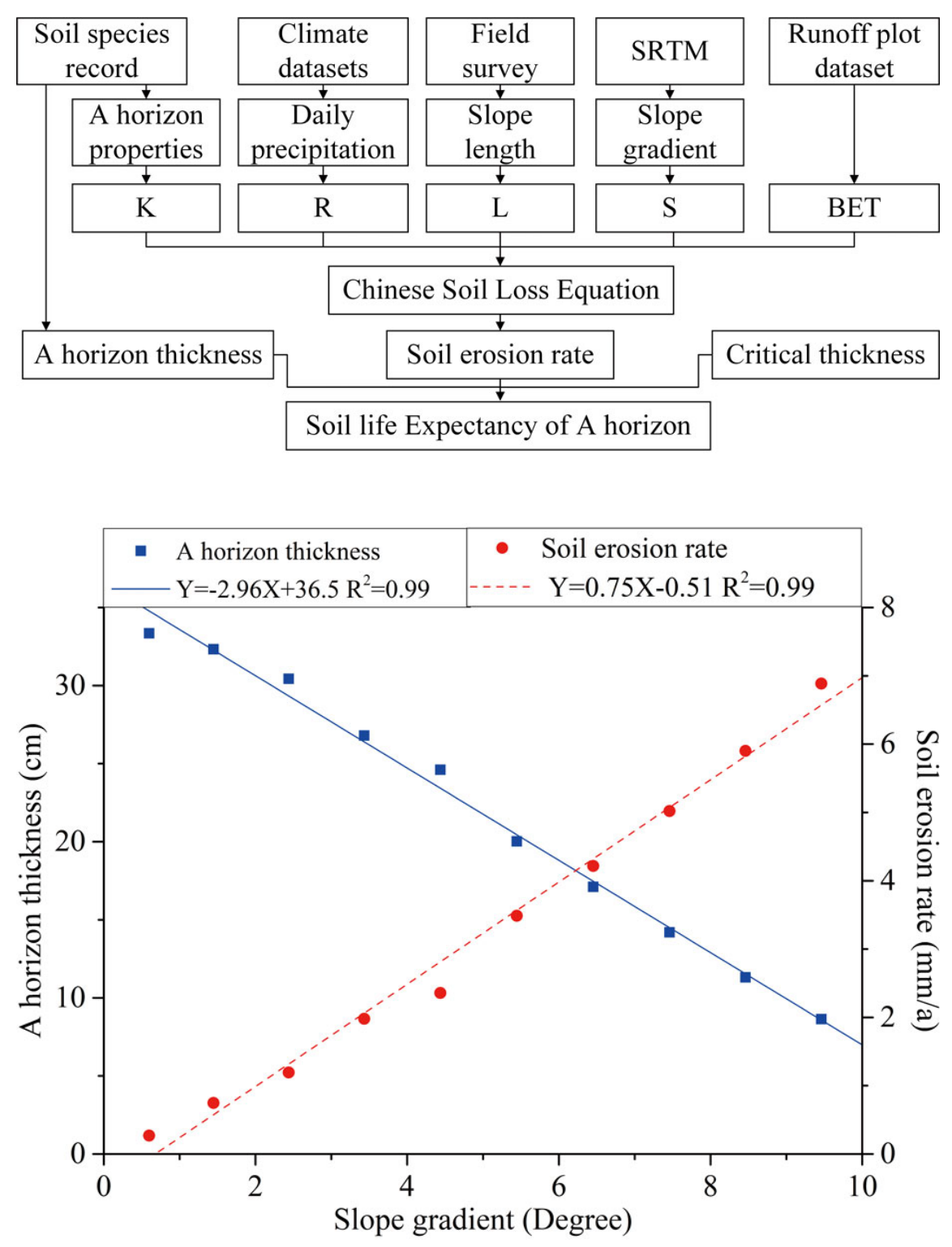


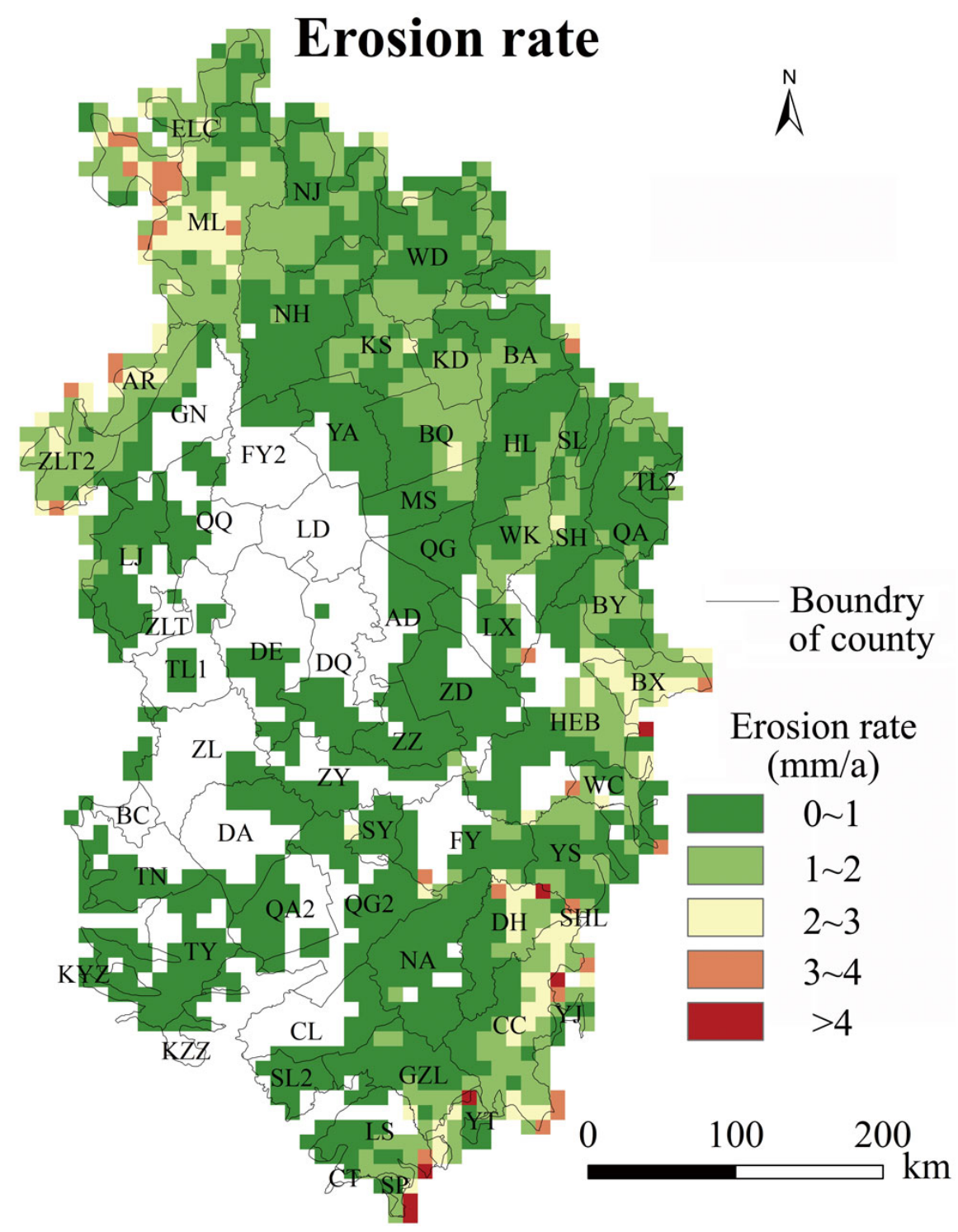




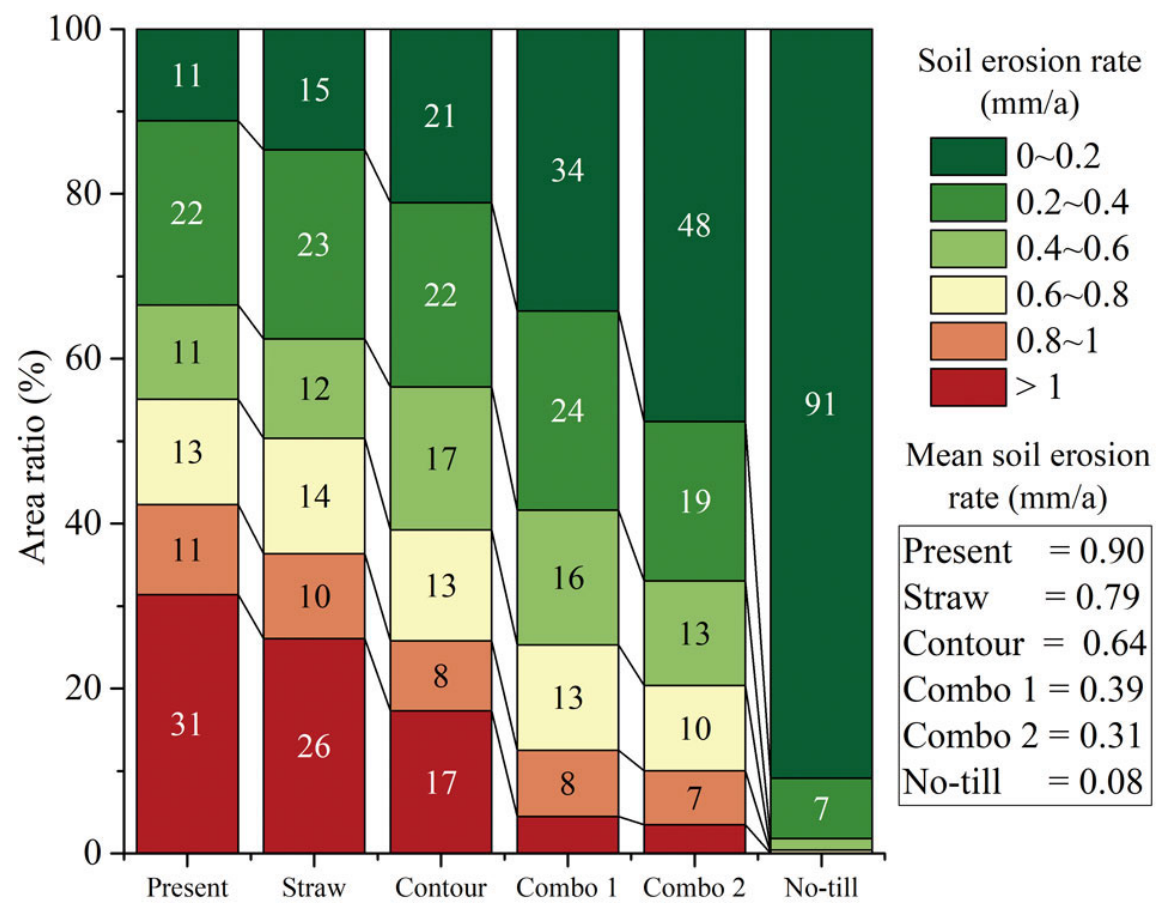




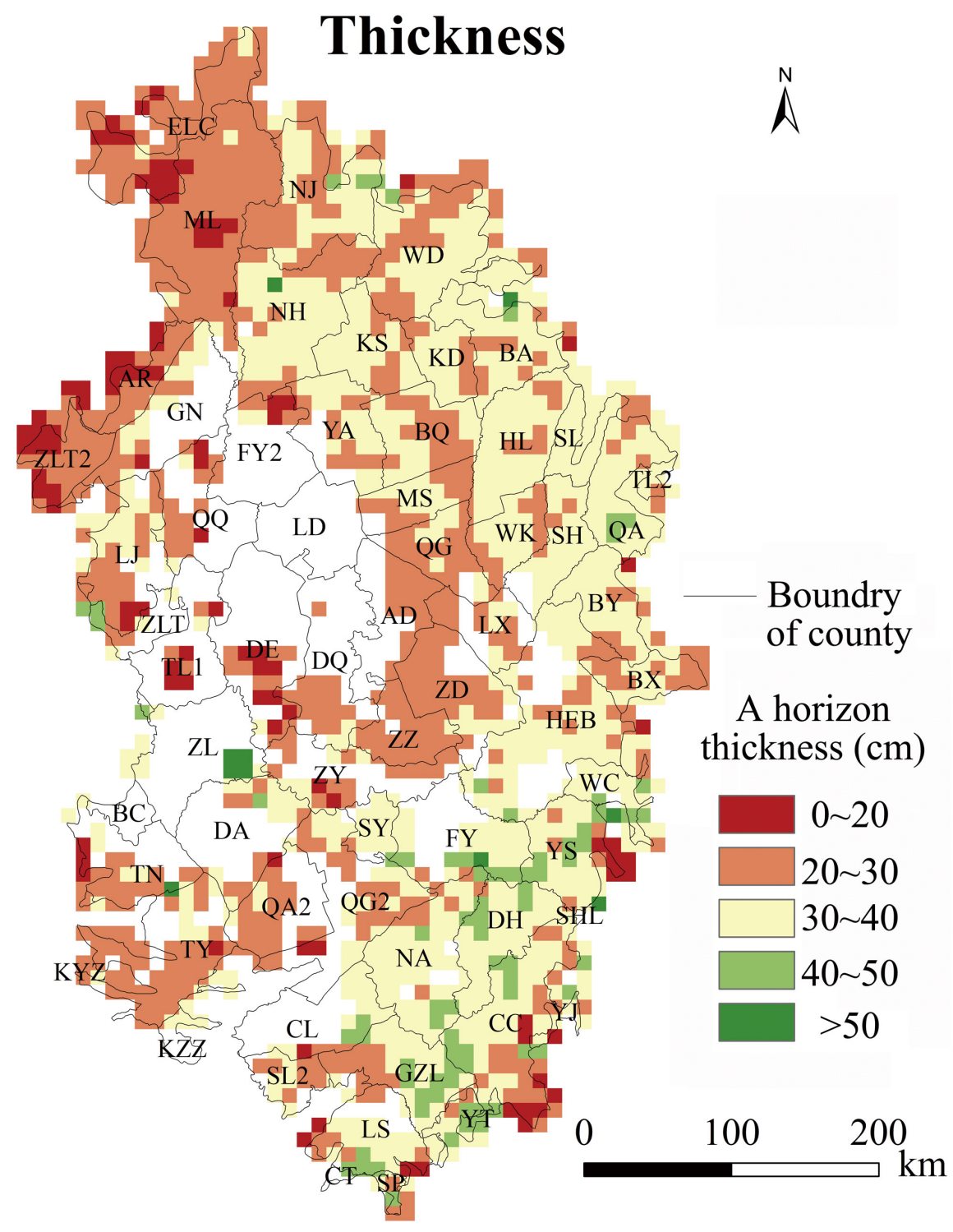



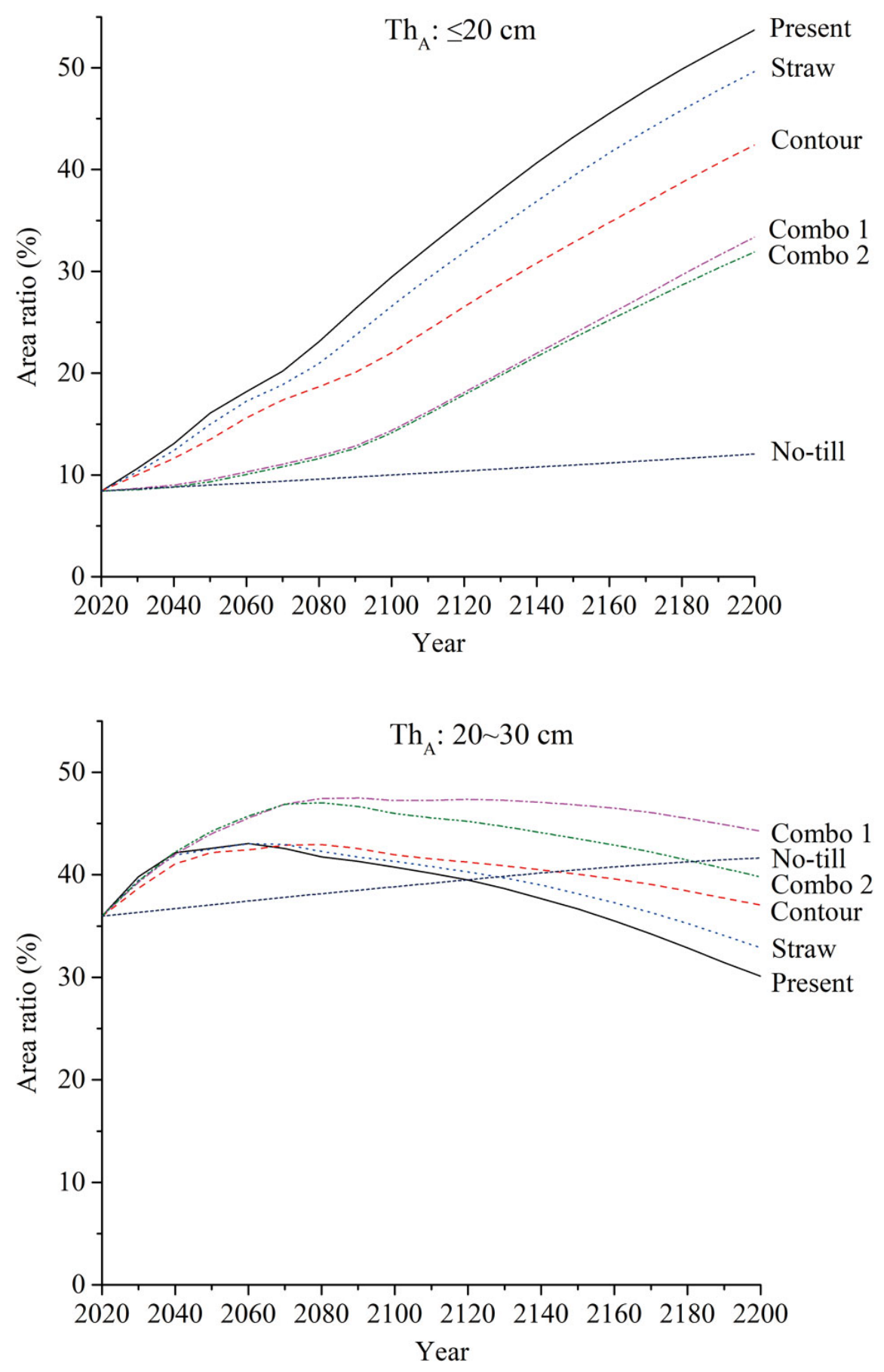

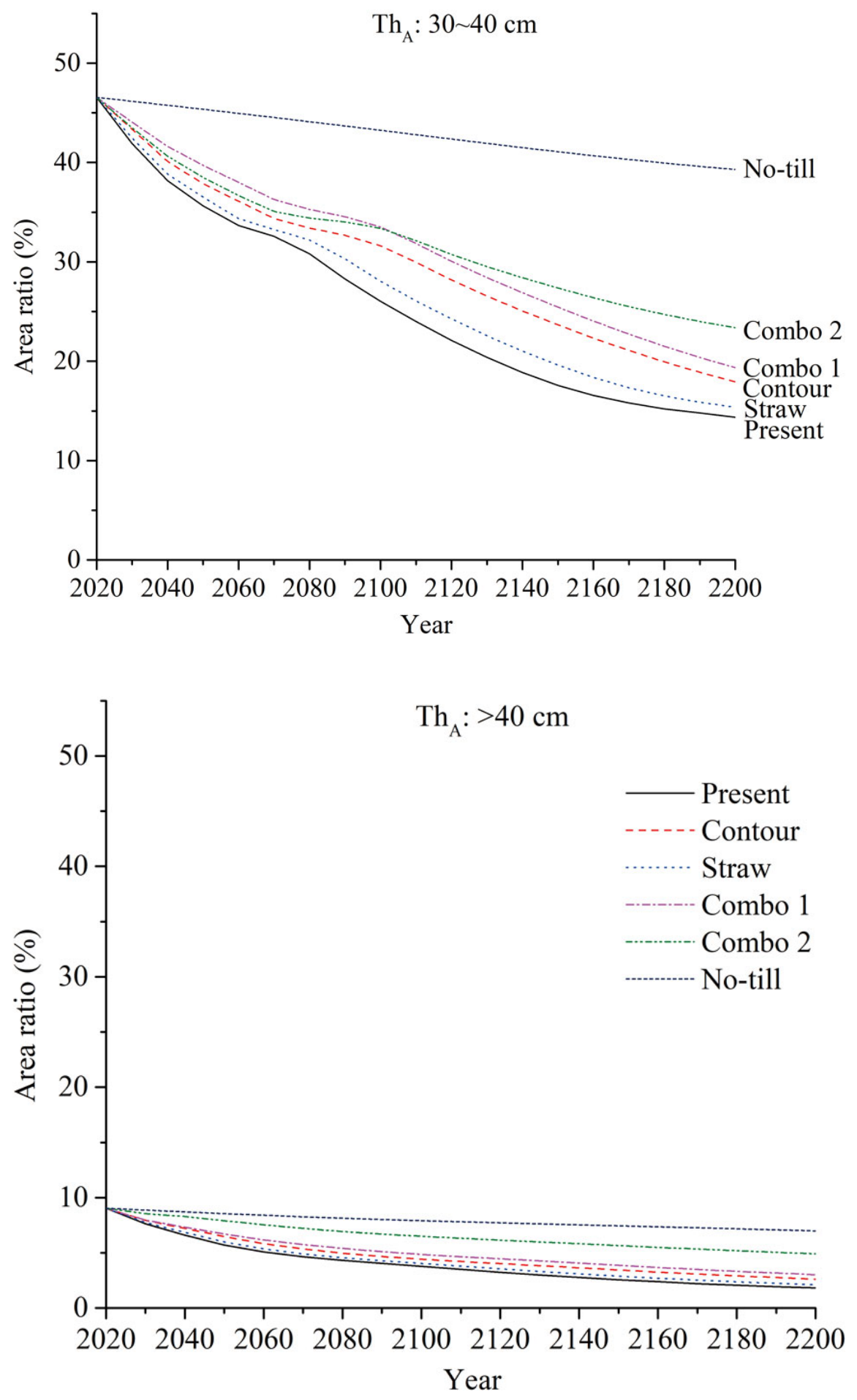


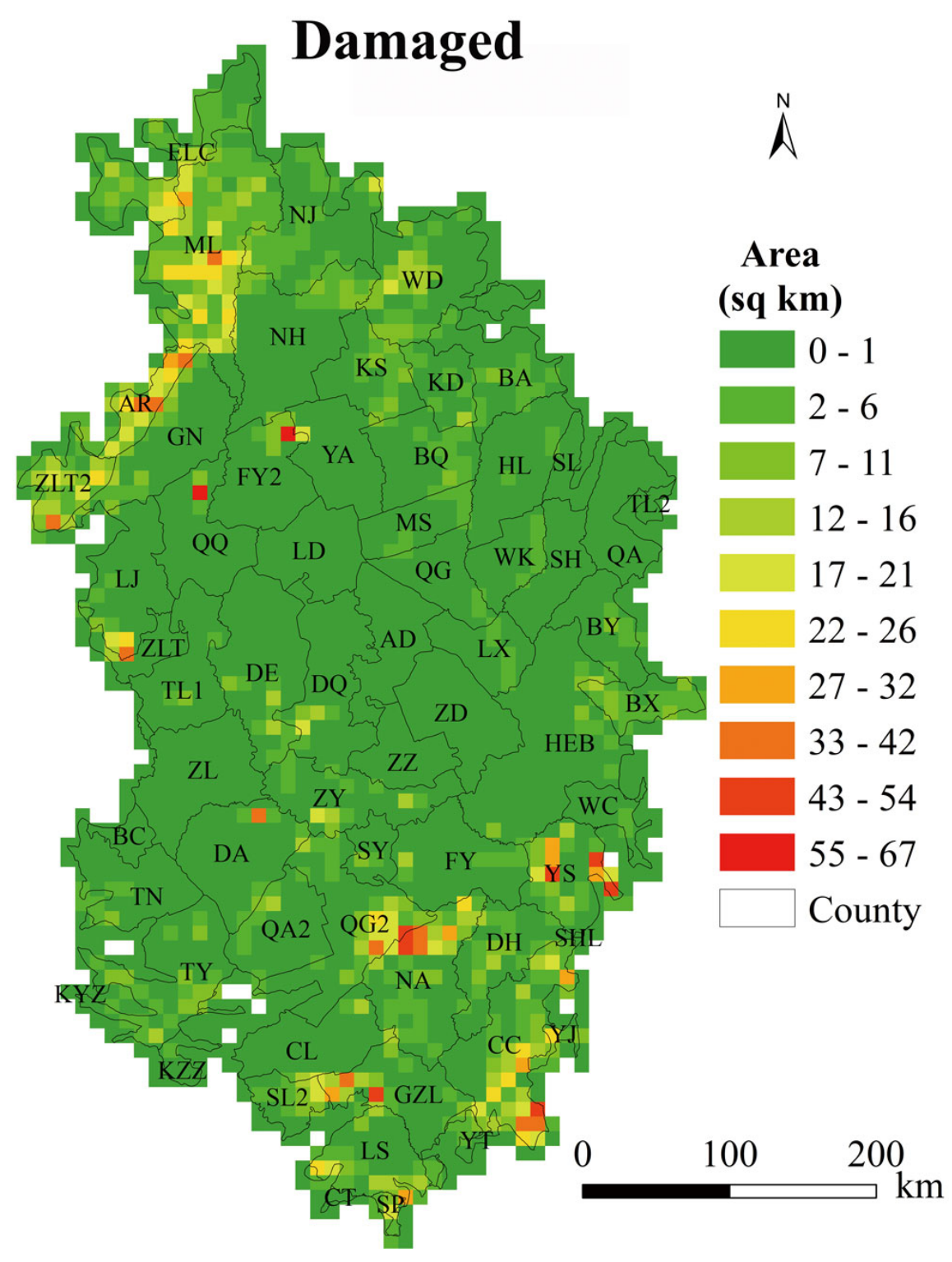




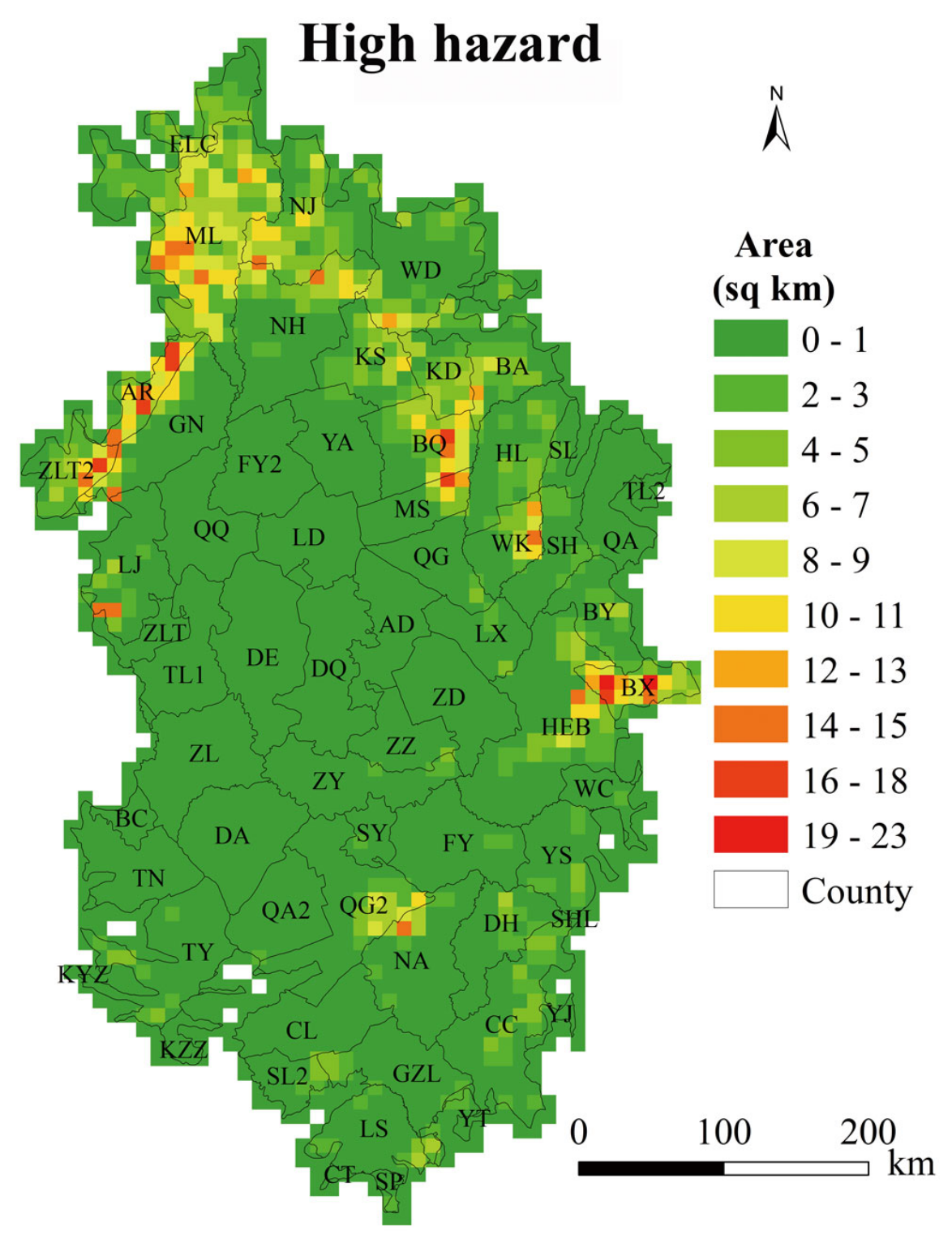




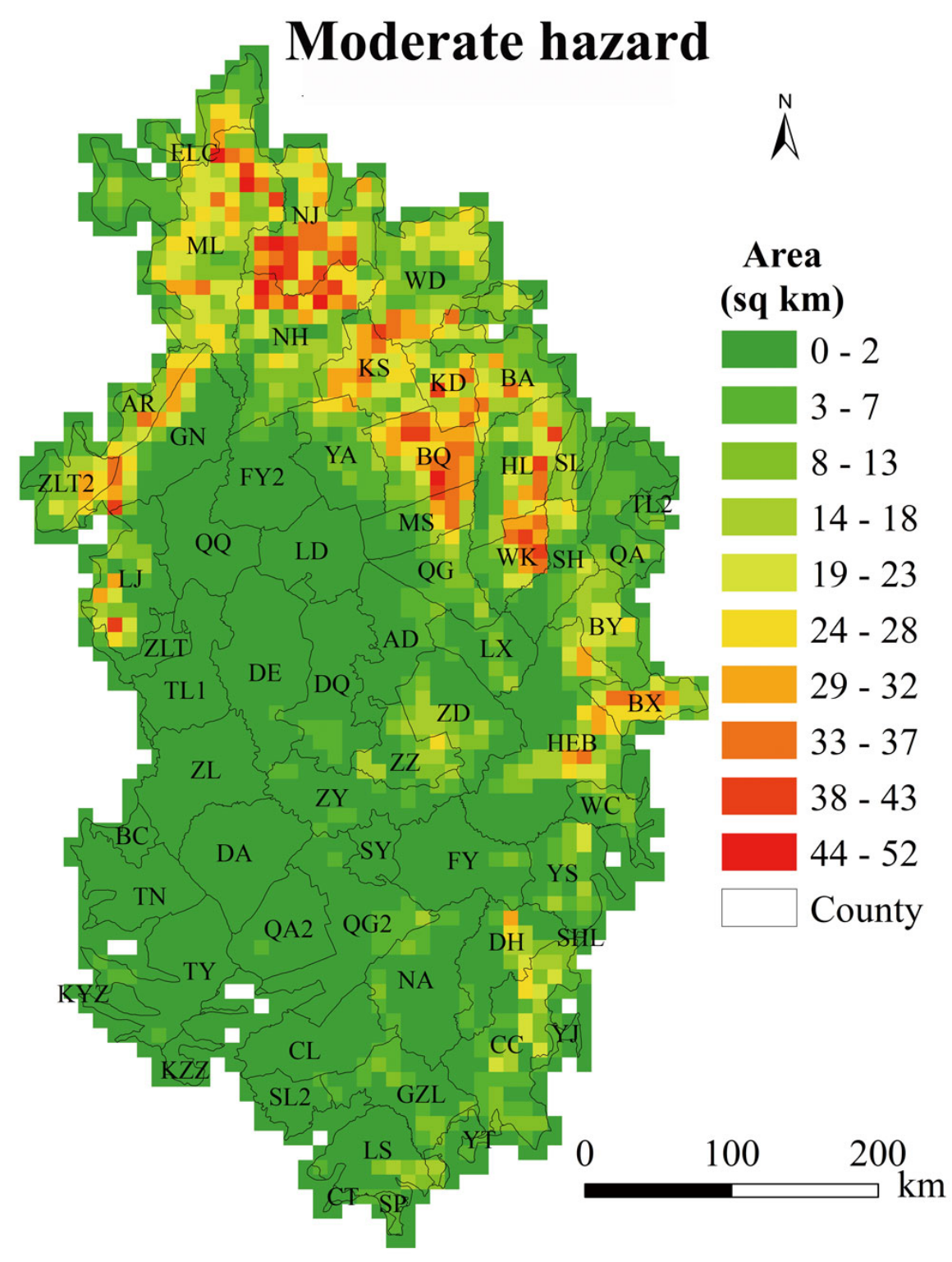




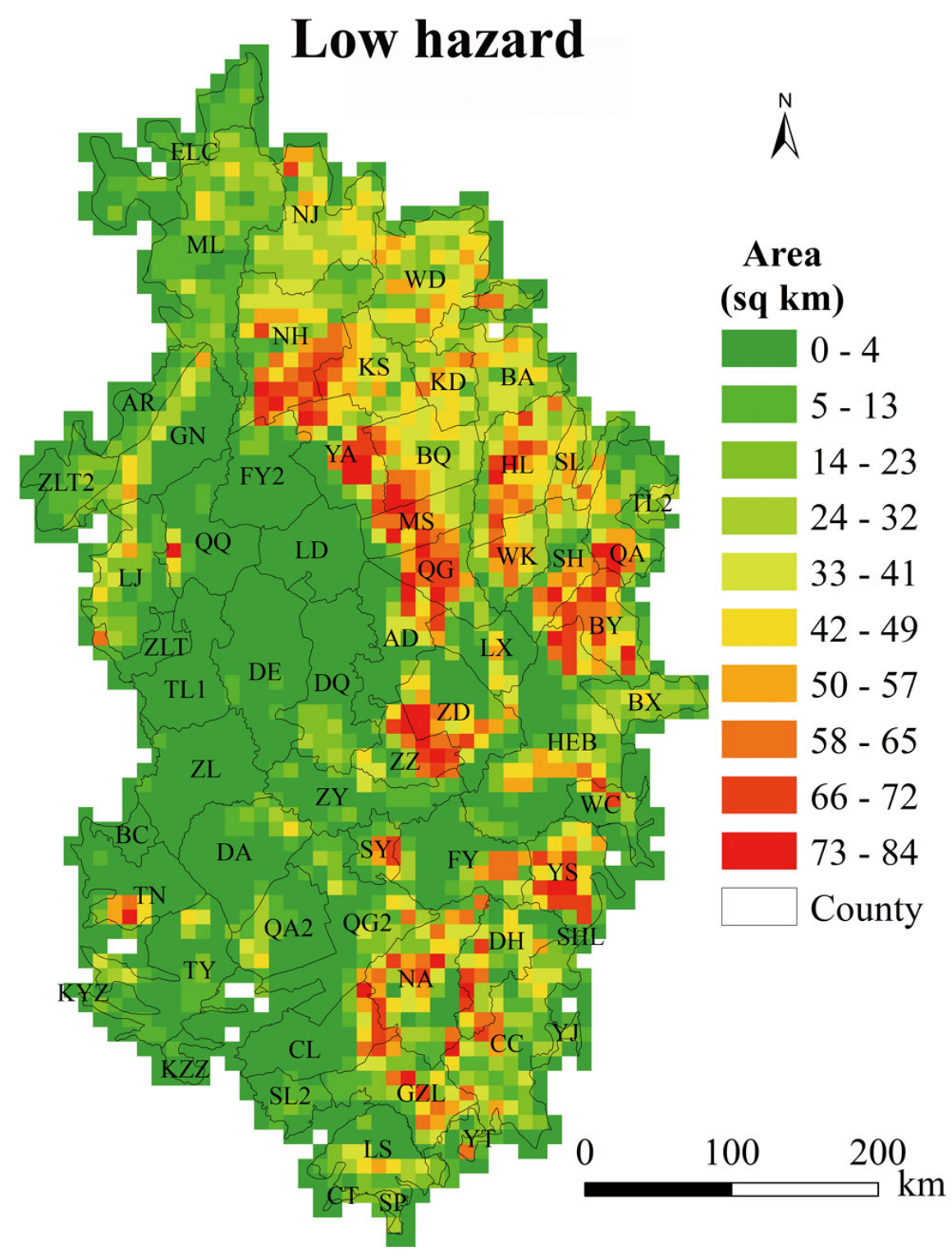




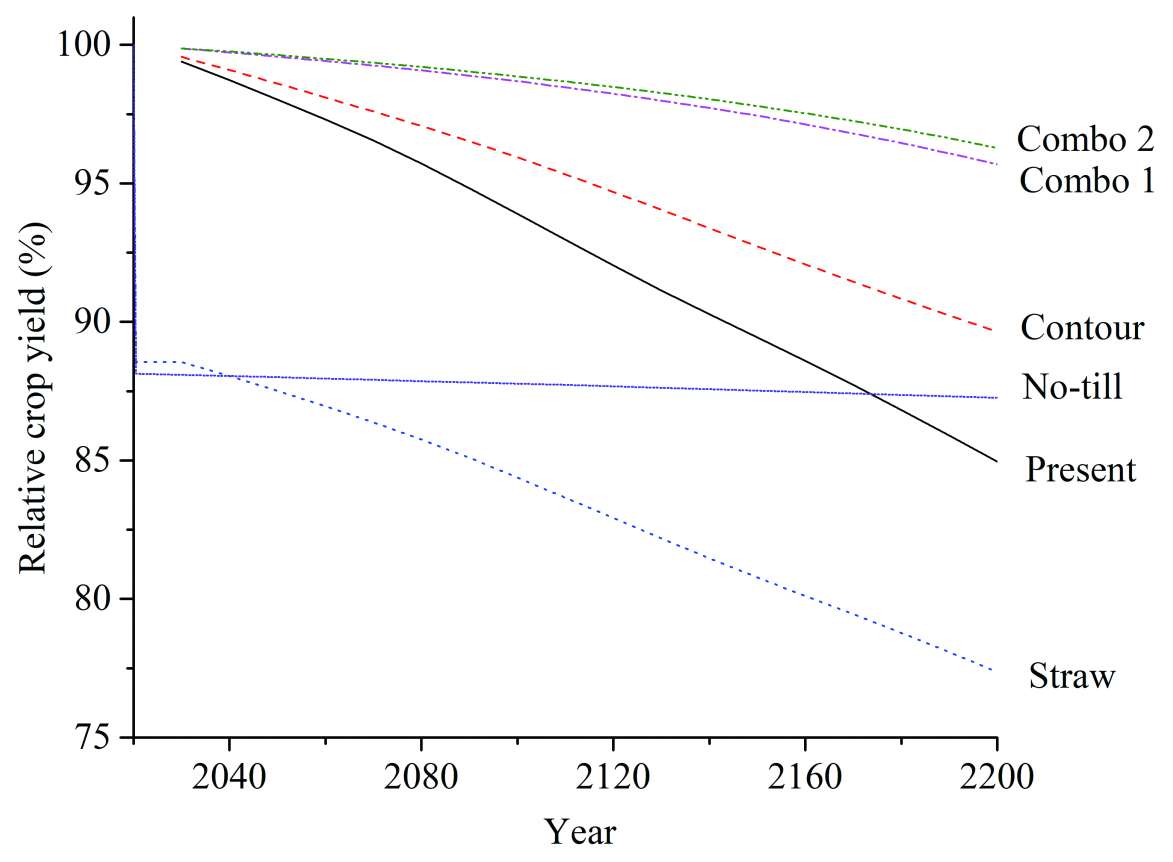




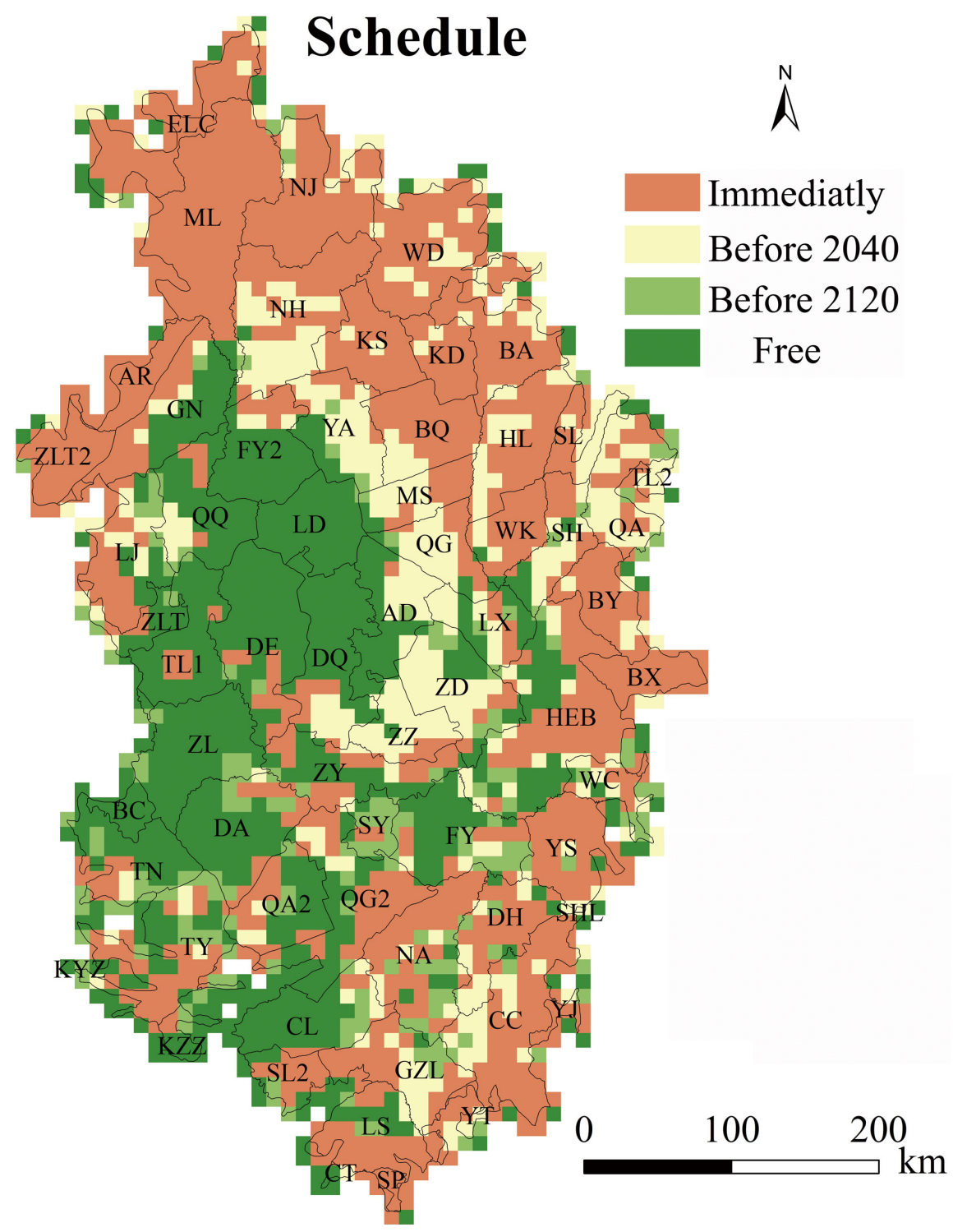

